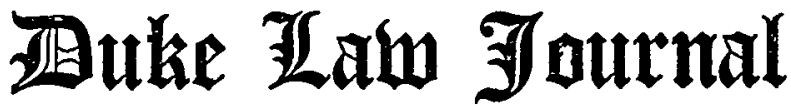

VOLUME 1964 SPRING NUMBER ?

\section{A PRACTICAL GUIDE TO THE RULE AGAINST PERPETUITIES}

\author{
ROBERT J. LYNN*
}

\section{INTRODUCTION}

$T$ HE CLASSIC American treatise on the common law Rule Against Perpetuities is John Chipman Gray's The Rule Against Perpetuities. ${ }^{1}$ The classic article on the Rule is W. Barton Leach's "Perpetuities in a Nutshell."2 Although several generations removed from Gray, Leach has joined him in shaping the Rule. ${ }^{3}$ Gray made the Rule a rule against remoteness of vesting. ${ }^{4}$ By insisting on the appropriate use of techniques which save gifts from invalidity under the Rule, Leach has made the Rule a sensible member of a family of related rules which regulate the devolution of wealth from generation to generation. 5

Leach's attacks on the Rule in classic form antedate World War II. Intensified after the close of the war, ${ }^{6}$ they were paralleled by

* B.S. 1942, J.D. 1948, Ohio State University; J.S.D. 1952, Yale University; contributor to legal periodicals. Professor of Law, Ohio State University. The author is indebted to Mr. William M. Connelly of the Class of 1964, Ohio State University School of Law, for his valuable assistance in the preparation of this article.

${ }^{1}$ First published in 1886, the last (fourth) edition, prepared by the author's son Roland, was published in I942.

5 I HaRv. L. REv. 638 (1938).

${ }^{3}$ Perpetuities in a Nutshell is the most popular of Professor Leach's early articles on the Rule. A companion article, The Rule Against Perpetuities and Gifts to Classes, 51 Harv. L. REv. 1329 (1938), is frequently cited. Leach, Powers of Sale in Trustees and the Rule Against Perpetuities, 47 Harv. L. Rev. 948 (1934), is the first in the series.

- Guluiver, Cases on future Interests 76 (1959).

- For evidence of Leach's influence on decisions, see Lanier v. Lanier, $218 \mathrm{Ga} .137$, 126 S.E.2d 776 (1962); Second Bank-State St. Trust Co. v. Second Bank-State St. Trust Co., 335 Mass. 407, 140 N.E.2d 201 (1957); Carter v. Berry, 243 Miss. 321, 136 So. 2d 871,140 So. 2d 843 (1962).

'Leach's renewed attacks on absurd applications of the Rule began with Perpetuities in Perspective: Ending the Rule's Reign of Terror, 65 HARV. L. REv. 721 
a reform movement which Leach did not originate ${ }^{7}$ but later joined. ${ }^{8}$ Briefs of both the reformers ${ }^{9}$ and the traditionalists ${ }^{10}$ are available elsewhere. Here it is assumed (1) that the reform movement will persist, (2) that the Rule in orthodox form will endure, and (3) that the practitioner and the student want to know how the Rule works irrespective of the form it takes from time to time or from place to place. This article implicitly describes how Leach has tempered Gray's classic Rule, and in particular it (1) shows the mechanics of the Rule, given ideal limitations, (2) demonstrates that assimilating an actual case to the ideal is frequently difficult, and (3) suggests methods of avoiding the impact of the Rule at both the drafting and construction stages of estate work.

I

\section{IN GENERAL}

The common law Rule Against Perpetuities exists in orthodox form in about three fourths of the jurisdictions in the United States. ${ }^{11}$ Although about one fifth of the states have had statutory substitutes for the common law Rule, ${ }^{12}$ the tendency over the years has been to return to the common law Rule in orthodox form. ${ }^{13}$ In

(1952). Leach drew on all of his earlier work when collaborating with Tudor on $\$$ 24 of the American Law of Property on the common law Rule. 6 American Law OF Property $\$ \S$ 24.1-.68 (Casner ed. 1952) [hereinafter cited A.L.P.].

'For his disclaimers of originality, see Leach, Perpetuities Legislation: Hail, Pennsylvania! 108 U. PA. L. REv. I124 (1960).

${ }^{8}$ Ibid.

${ }^{\circ} 6$ A.L.P. $\$$ 24.11; Brégy, A Defense of Pennsylvania's Statute on Perpetuities, 23 TEMP. L.Q. 313 (1950); Dukeminier, Kentucky Perpetuities Law Restated and Reformed, 49 KY. L.J. I (1960); Leach, Perpetuities Legislation, Massachusetts Style, 67 HARv. L. REv. 1349 (1954).

103 Simes \& SMITH, FUTURE INTERESTS $\$ 1230$ (2d ed. 1956) [hereinafter cited as Stmes \& SMITH]; Mechem, Further Thoughts on the Pennsylvania Perpetuities Legislation, 107 U. PA. L. REv. 965 (1959); Simes, Is the Rule Against Perpetuities Doomed? 52 Mrch. L. Rev. 179 (1953); Sparks, A Decade of Transition in Future Interests, 45 VA. L. REv. 493 (1959).

${ }^{11} 6$ A.L.P. $\$ 25.1$. Professor Whiteside's estimate of more than ten years ago is still accurate despite shifts from the Rule in orthodox form to a less stringent version and returns to the Rule in orthodox form by jurisdictions having a statutory substitute.

126 A.L.P. $\S \S 24.5,25.1$.

${ }^{13}$ California is the most important of the states which have returned recently to the common law Rule. Recent Legislation, Future Interests: Recent Changes in the Law of Future Interests in California, 48 CALIF. L. REv. 134 (1960). The Rule in California was modified in 1963 by the repeal of $\$ \$ 693,694$, and 695 of the Civil Code (defining vested and contingent future interests), and the enactment of $\$ \S 715.5$ (establishing cy pres), 715.6 (establishing a sixty year period in gross), 715.7 (eliminating the "unborn widow" construction), and 715.8 (redefining a vested inter- 
1947 Pennsylvania reformed the common law Rule by enacting what is called a "wait and see" statute. It provides that "upon the expiration of the period allowed by the common law rule against perpetuities as measured by actual rather than possible events any interest not then vested and any interest in members of a class the membership of which is then subject to increase shall be void."14 A number of other states by legislation or judicial decision have adopted a "wait and see" version of the Rule. ${ }^{15}$ In 1963 California reformed the common law Rule by enacting what is called a cy pres statute. It provides that

No interest in real or personal property is either void or voidable as in violation of ... [the Rule Against Perpetuities] if and to the extent that it can be reformed or construed within the limits of ... [the Rule] to give effect to the general intent of the creator of the interest whenever that general intent can be ascertained. This section shall be liberally construed and applied to validate such interest to the fullest extent consistent with such ascertained intent. ${ }^{16}$

Several states, including Kentucky, have coupled "wait and see" with the cy pres principle to mitigate the effects of applying the Rule in orthodox form. Kentucky's "wait and see" plus cy pres statute is as follows:

In determining whether an interest would violate the rule against perpetuities the period of perpetuities shall be measured by actual rather than possible events; provided, however, the period shall not be measured by any lives whose continuance does not have a causal relationship to the vesting or failure of the interest. Any interest which would violate said rule as thus modified shall be reformed, within the limits of that rule, to approximate most closely the intention of the creator of the interest. ${ }^{17}$

est). CAx. Crv. Cone ANN. (Supp. 1963). The constitutionality of $\$ 715.8$ (intended to abrogate the rule of Haggerty v. City of Oakland, 161 Cal. App. 2d 407, 326 P.2d 957 (1958)) has already been doubted. Review of 1963 Code Legislation, 38 CALIF. ST. B.J. 643 (1963).

14 PA. Stat. ANN. tit. 20, $\$ \S 301.4-5$ (1950); Brégy, supra note 9.

${ }^{25}$ In limited or modified form, "wait and see" exists in Connecticut, Maine, Maryland, and Massachusetts. ConN. GEN. STAT. ANN. $\$ 45-95$ (1960); ME. REv. STAT. ANN. ch. 160, § 27 (Supp. 1963); Mo. ANN. Code art. 16, § 197A (Supp. 1963); MAss. ANN. LAws ch. 184A, $\S 1$ (1955). New Hampshire adopted "wait and see" by judicial decision. Merchants Nat'I Bank v. Curtis, 98 N.H. 225, 97 A.2d 207 (1953).

${ }^{10}$ Cal. Civ. Code ANn. $\$ 715.5$ (Supp. 1963). See also note 13 supra.

${ }_{17}$ KY. REv. STAT. ANN. \& 381.216 (1963). Vermont and Washington have coupled "wait and see" with cy pres. VT. STAT. ANN. tit. 27, §501 (1959); WASH. REv. Code ANN. $\$ \S 11.98 .010-.030$ (1963) (applicable to interests created by trusts). New Hampshire adopted cy pres by judicial decision. Edgerly v. Barker, 66 N.H. 434, 31 Atl. 900 (1891). The Idaho perpetuities statute, the most unsatisfactory of those recently 
Of the some eighteen states which have had statutory substitutes for the common law Rule, thirteen adopted statutes that were derived from or influenced by the New York Revised Statutes of 1830.18 Although none of the thirteen adopted the New York statutes in their entirety, problems presented by the statutes in those thirteen states are similar to the problems presented by the corresponding statutes in New York. ${ }^{19}$ Because the return to the common law Rule Against Perpetuities in orthodox form has been sporadic, it is important in a jurisdiction having the Rule in orthodox form to know just how long the Rule has been accepted in that form. The proper interpretation of a document may turn on applying a perpetuities statute that has been repealed. Conversely, in a jurisdiction having "wait and see" or cy pres, or "wait and see" coupled with cy pres, it is important to know just how long the innovation has been in force. All references to the Rule in this article are to the Rule in orthodox form unless otherwise indicated.

II

\section{StaTement OF THE RULE}

The most frequently quoted statement of the common law Rule Against Perpetuities is that of John Chipman Gray: "No interest is good unless it must vest, if at all, not later than twenty-one years after some life in being at the creation of the interest."20 Leach suggests that Gray's statement should be preceded by the words "generally speaking" and that "vest" should be put in quotation marks. ${ }^{21}$ The Rule invalidates an interest which might vest, if it vests at all, at a remote time. A contingent future interest which might vest remotely, if it vests at all, is said to be bad or void or invalid under the Rule. The Rule is not concerned with interests so created that they must vest, if they vest at all, within the perpetuities period. Nevertheless, a contingent future interest which must vest, if it vests at all, within the permissible period is conventionally said to be good or valid under the Rule.

enacted, may include a cy pres feature applicable to interests created by trusts. IDAko CoDE ANN. $\$ \$ 55-111$ (1957). The limited "wait and see" statutes of Connecticut, Maine, Maryland, and Massachusetts are complemented by a cy pres feature. See note 13 supra for a résumé of changes in the Rule recently effected in California. ${ }^{18} 6$ A.L.P. \& 25.1 .

10 Ibid.

${ }^{20}$ Gray, The Rule Against Perpetuities 191 (4th ed. 1942) [hereinafter cited as GrAY].

${ }^{21}$ Leach, Perpetuities in a Nutshell, 51 HARv. L. REv. 638, 639 (1938). 
The common law Rule Against Perpetuities is a rule against remoteness of vesting. ${ }^{22}$ A contingent future interest is invalid under the Rule if, at the time of the creation of the interest, the circumstances are such that the contingency may go unresolved for too long a time. The Rule is not concerned with the duration of interests, that is, the length of time that they endure. ${ }^{23}$ It is not a rule against suspension of the power of alienation, ${ }^{24}$ nor a rule against restraints on alienation. ${ }^{25}$ It is not a rule which limits directly the duration of trusts. ${ }^{26}$ If $A$, owning land in fee simple absolute, ${ }^{27}$ grants "to $T$ and his heirs, in trust, to pay the net income to $B$ for life, then to pay the net income to the children of $B$ for their lives, and then to convey to $C$ and his heirs," and "children of $B$ " is construed to mean "children of $B$ whenever born," there is no violation of the Rule Against Perpetuities even though the trust may endure beyond the perpetuities period. The Rule is satisfied if all contingent future interests are so created that they must vest, if they vest at all, within the perpetuities period. ${ }^{28}$

\section{III}

\section{INTERESTS SUBJEGT to AND EXEMPT FROM THE RULE}

The Rule Against Perpetuities is not concerned with present or immediate interests or with future interests which are vested at their creation. Reversions, ${ }^{29}$ possibilities of reverter, ${ }^{30}$ and remainders indefeasibly vested ${ }^{31}$ are exempt from the Rule. Rights of entry for condition broken ${ }^{32}$ and resulting trusts ${ }^{33}$ are unaffected by the Rule. On principle, the Rule should not apply to indefeasibly vested executory interests, but there is little authority on

\footnotetext{
${ }^{22}$ GRAY 3.

${ }^{23} 6$ A.L.P. $\$ 24.3$.

24 Ibid.

${ }^{25} \mathrm{Ibid}$.

${ }_{20}$ Id. $\$ 24.67$.

${ }^{27}$ In the hypothetical cases put hereafter, assume that $A$, the grantor, settlor, or testator (as the case may be) owns land in fee simple absolute or owns personalty absolutely.

${ }^{28}$ The Rule does limit the duration of private express trusts indirectly by invalidating contingent future interests which might vest remotely, thus simplifying termination through death of the beneficiaries or through consent by the beneficiaries. 1 Scort, TRUsts $\$ 62.10$ (2d ed. 1956).

203 Simes \&: SMITH $\$ \$ 1235,1240$.

${ }^{30} I d$. $\$ 1239$.

${ }^{31} I d . \S 1235$.

${ }^{33} I d$. \$ 1238.

${ }^{3} I d . \& 1240$.
} 
the point. $^{34}$ The common law Rule Against Perpetuities is primarily concerned with gift transactions for family purposes and not with commercial transactions. The Rule does not apply to options to renew leases for years ${ }^{35}$ or to options contained in leases for years to purchase the reversion during the continuance of the term..$^{36}$ On principle, the Rule should not apply to equitable interests of promisees of specifically enforceable contracts to transfer property ${ }^{37}$ Interests created by employee benefit trusts are commonly exempt from the Rule by statute.

The Rule Against Perpetuities applies to contingent remainders $^{38}$ and contingent executory interests, ${ }^{39}$ the kinds of future interests commonplace in deeds, wills, and trusts. Although the Rule is not ordinarily concerned with commercial transactions, it does apply to options to purchase land when not incident to a lease for years and exercisable during its continuance. An option in gross (as it is called) to purchase land is void under the Rule if it is exercisable beyond the perpetuities period. ${ }^{40}$

\section{IV}

\section{OpERATION OF THE RULE}

\section{A. In General}

From the fact that a contingent remainder or a contingent executory interest complies with the requirements of the Rule Against Perpetuities, it does not follow that it necessarily will vest. The Rule requires that a contingent future interest be so created that it must vest, if it vests at all, within the perpetuities period. A contingent future interest which is good under the Rule may never in fact vest because it fails by virtue of its own limitation. If $A$ grants "to $B$ for life, remainder to $C$ and his heirs if $C$ survives $B$," the contingent remainder is good under the Rule because $C$ will survive $B$, or not, within the lives of either $B$ or $C$, and both are lives in being at the time of the grant. Therefore, the contingency will be resolved within the perpetuities period. If $C$ does not survive $B$, the contingent remainder, though good under the Rule

\footnotetext{
${ }^{34} I d . \S 1236$.

${ }^{35} I d$. $\$ 1243$.

${ }^{36}$ Id. $\$ 1244$.

${ }^{37} 1 d . \S 1245$.

${ }^{38} I d$. $\$ 1237$.

${ }^{30} I d$. $\$ 1236$.

${ }^{10} 1 d$. $\$ 1244$.
} 
Against Perpetuities, never vests. It fails by virtue of its own limitation.

The test for validity of a contingent future interest under the Rule Against Perpetuities in orthodox form is a possibilities test, not a probabilities test or an actualities test. ${ }^{41}$ If the contingency might be resolved at a remote time, the contingent future interest is bad $a b$ initio under the Rule even though it is probable at the creation of the interest that the contingency will be resolved within the perpetuities period, or even though the contingency ultimately is resolved within the perpetuities period. Possibilities are considered as of the time the interest is created-commonly, on delivery of a deed or at the death of a testator-and a declaration of invalidity is then permissible. If $A$ devises "to $B$ for life, remainder to that son of $B$ who first attains twenty-five," and no son of $B$ has attained twenty-five at $A$ 's death and "son" is construed to mean "son whenever born," the contingent remainder is bad under the Rule. It is bad although $X$, a son of $B$ alive at $A$ 's death, is twenty-four years old at $A$ 's death. It is bad although $X$ ultimately attains twenty-five. It is bad although the perpetuities question is raised after both $B$ and $X$ are dead. Under the cy pres version of the Rule, the contingent remainder may be reformed to read "remainder to that son of $B$ who first attains twenty-one," thereby saving it from invalidity.

By contrast, the test for validity of a contingent future interest under the Rule Against Perpetuities in "wait and see" form is an actualities test. ${ }^{42}$ If the contingency might be resolved at a remote time, the contingent future interest is not necessarily bad $a b$ initio under the "wait and see" version of the Rule.43 If $A$ devises "to $B$ for life, remainder to that son of $B$ who first attains twenty-five," and no son of $B$ has attained twenty-five at $A$ 's death and "son" is construed to mean "son whenever born," determination of validity of the contingent remainder may be deferred to a time beyond $A$ 's death. If a son of $B$ alive at $A$ 's death or born thereafter has attained twenty-five at $B$ 's death, the contingent remainder is good under "wait and see" because it has in fact vested within the perpetuities period, namely the lives of $B$ and $B$ 's sons alive at $A$ 's death and

$\$ 16$ A.L.P. $\$ 24.21 ; 3$ SIMES \& SMTTH § 1228.

43 Simes \& SMIrH $\S 1230$. Professor Simes thinks wait and see is "inherently unsound." Ibid.

${ }^{* 3}$ The contingent remainder is bad at $A$ 's death even under "wait and see" if $B$ is childless at $A$ 's death and is incapable of conceiving a child. A declaration of invalidity is permissible under "wait and see" at $A$ 's death because no purpose is served by deferring determination of validity until a later time. 
twenty-one years. However, if the only son of $B$ is conceived and born after $A$ 's death and has attained but three years of age at $B$ 's death, the contingent remainder is bad even under "wait and see" because $B$ 's life is the only relevant life in being at $A$ 's death; and $B$ 's afterborn son cannot attain twenty-five within twenty-one years after $B$ 's death. If cy pres is coupled with "wait and see," the contingent remainder under such circumstances is reformed at $B$ 's death to read "remainder to that son of $B$ who first attains twenty-one," thereby saving it from invalidity under the Rule. ${ }^{44}$

The Rule applies to both legal and equitable interests. ${ }^{45}$ If a jurisdiction retains the destructibility rule with respect to legal contingent remainders in land, 46 a contingent remainder which otherwise would be bad under the common law Rule Against Perpetuities is good under the Rule if the contingent remainder is so created that it must vest, if at all, or be destroyed under the destructibility rule, within the perpetuities period. ${ }^{47}$ If $A$, owning land in fee simple absolute, devises "to $B$ for life, remainder to that son of $B$ who first attains twenty-five," and $B$ is a bachelor at $A$ 's death, the contingent remainder is ordinarily bad under the Rule. But if the destructibility rule exists, the contingent remainder is good under the Rule Against Perpetuities because it must vest, if at all, during $B$ 's lifetime, or be destroyed under the destructibility rule at $B$ 's death if still contingent at $B$ 's death. Because the contingent remainder must vest, if at all, or be destroyed, as the case may be, within the lifetime of a person alive at $A$ 's death, the requirements of the Rule are satisfied.

\section{B. Demonstrating Validity Under the Rule- Measuring the Perpetuities Period}

The perpetuities period is any reasonable number of lives in being at the creation of the interest, plus actual periods of gestation and twenty-one years. ${ }^{48}$ If a contingent future interest is created by deed, the perpetuities period ordinarily begins to run upon delivery

\footnotetext{
4t Dukeminier, Perpetuities Law in Action 84 (1962) [hercinafter cited as DukeMINIER].

15 6 A.L.P. $\S 24.5$ A.

to Professor Dukeminier found that only in Florida is it clear that the destructibility rule prevails. In eleven states the existence of such a rule is uncertain. Dukeminier, Contingent Remainders and Executory Interests: A Requiem for the Distinction, 43 Minn. L. REv. 13, $38-39$ (1958).

173 SINES \& SMITH $§ 1231$.

186 A.L.P. § 24.12.
} 
of the deed. ${ }^{49}$ If a contingent future interest is created by will, the perpetuities period begins to run on the death of the testator. ${ }^{50}$ If a contingent future interest is created by a revocable deed of trust, the deed of trust is for perpetuities purposes like a will, and the perpetuities period begins to run at the death of the grantor rather than upon delivery of the deed. ${ }^{51}$

\section{Demonstrating Validity Under the Rule in Orthodox Form}

Although it is sometimes said that any life can be used as the "life in being at the creation of the interest" to demonstrate the validity of a contingent future interest under the Rule, this statement is accurate only in a limited sense. The life used to demonstrate validity need not be mentioned in the dispositive instrument, and it need not be the donee of a gift under the instrument. ${ }^{52}$ Furthermore, the draftsman may provide a reasonable number of lives in being to be used for the express purpose of measuring the perpetuities period. ${ }^{53}$ In the ordinary case, one must decide what "life in being at the creation of the interest" (if any) is to be used to demonstrate validity of a contingent future interest under the Rule.

Because grantors and testators commonly make gifts to several generations, the life used to demonstrate validity often is that of a life tenant of land or a life income beneficiary of a trust. If $A$ bequeaths $\$ 100,000$ "to $T$ and his heirs, in trust, to pay the net income to $B$ for life, then to pay the net income to the children of $B$ for their lives, and then to pay the principal to $C$ and his heirs," and "children of $B$ " is construed to mean "children of $B$ whenever born," the life of $B$ is used to demonstrate the validity of the gifts to children of $B$ unborn at $A$ 's death. ${ }^{54}$ Any child of $B$ will be born within $B$ 's lifetime (and an actual period of gestation). Therefore, any gift of income to a child of $B$ unborn at $A$ 's death, if any, will vest within the perpetuities period. If a gift of income is so created that it must vest, if at all, within the perpetuities period, it is irrelevant that it may endure beyond the perpetuities period. If $X$, a child of $B$, is born after $A$ 's death and during the continuance of

\footnotetext{
\$0 6 A.L.P. § 24.12; 3 SIMES \& SMITH $§ 1226$.

${ }^{\circ}$ Ibid.

"I Ibid.

"2 6 A.L.P. § 24.13; 3 SIMES \&. SMITH $§ 1223$.

${ }^{63}$ Ibid.

"4 Children of $B$ alive at $A$ 's death have vested remainders for life in the income, subject to open and subject to complete defeasance. I Simes \& SMITH $§ \S 113,114$.
} 
$B$ 's beneficial life interest, $X$ at birth has a vested beneficial interest for life in a proportionate share of trust income. Should $X$ survive $B, X$ 's beneficial interest for life might last beyond the lives of $B$ and $B$ 's children alive at $A$ 's death and twenty-one years, but the Rule Against Perpetuities is not concerned with the duration of interests. ${ }^{55}$ Should $X$ fail to survive $B$, X's vested beneficial interest for life will never become possessory. Like a contingent remainder, good under the Rule, which does not vest because the contingency is not resolved favorably with respect to the remainderman, the vested beneficial interest for life fails by virtue of its own limitation.

If $A$ bequeaths $\$ 100,000$ "to $T$ and his heirs, in trust, to pay the net income to $B$ for life, then to pay the net income to the children of $B$ for their lives, and then to pay the principal to the grandchildren of $B$," and "grandchildren of $B$ " is construed to mean "grandchildren of $B$ whenever born," the lives of $B$ 's children are used to demonstrate the validity of the gift to unborn grandchildren of $B$, just as the life of $B$ was used in the preceding example to demonstrate the validity of the gift of income to the unborn children of $B$. If "grandchildren of $B$ " is further construed to mean "grandchildren of $B$ whenever born to children of $B$ who predeceased $A$ or were alive at $A$ 's death," the gift to grandchildren is good under the Rule because any grandchild of $B$ born after $A$ 's death will be born within the lifetime of a child of $B$ alive at $A$ 's death (and an actual period of gestation). If, however, "grandchildren of $B$ " is construed to mean "grandchildren of $B$ whenever and to whomever born" and "children of $B$ " is construed to mean "children of $B$ whenever born," the lives of $B$ 's children cannot be used to demonstrate the validity of the gift to unborn grandchildren because a gift to a class stands or falls as a unit, and a child of $B$ unborn at $A$ 's death might have a child beyond the perpetuities period who would qualify to share in principal. Under such circumstances, the gift to grandchildren is bad under the Rule..$^{56}$

Frequently the life used to demonstrate validity is that of the donee of the contingent gift. If $A$ bequeaths $\$ 100,000$ "to such of $B, C, D$, and $E$ as are alive twenty-five years after my [ $A$ 's] death," the lives of the beneficiaries themselves are used to demonstrate the validity of the bequest. $B, C, D$, and $E$, persons alive at $A$ 's death,

${ }^{50} 6$ A.I.P. \$ 24.3.

${ }^{8}$ Id. $\$ \S 24.22, .25, .26$. 
will survive the lapse of twenty-five years, or not, within their own lives. When a condition of survivorship is attached to a gift to a specifically named person or a specifically identifiable person alive at the creation of the interest, the contingent gift is good under the Rule because the donee will survive to the required time, or not, within his own lifetime. If $A$ bequeaths $\$ 100,000$ "to such of my children as are alive twenty-five years after my $[A$ 's] death," the contingent executory interest is good under the Rule because a condition of survivorship is attached to a gift to specifically identifiable persons alive at $A$ 's death who will survive the running of the twenty-five year period, or not, within their own lives. From the fact that the contingent executory interest complies with the requirements of the Rule, it does not follow that it necessarily will vest. Gray says "vest, if at all ...."57 If no child of $A$ survives the running of the twenty-five year period, the gift fails by virtue of its own limitation.

Often the condition of survivorship is attached to a gift to a class, the membership of which is subject to increase because of possible births after the effective date of the instrument of transfer. If so, the lives of the donees cannot be used to demonstrate validity, ${ }^{58}$ and one should look to see whether the contingency is one which by its own terms must be resolved within the perpetuities period. If $A$ bequeaths $\$ 100,000$ "to such of my lineal descendants as are alive twenty years after my death," and "descendants" is construed to mean "descendants whenever born," the lives of the donees cannot be used to demonstrate validity; 59 but the contingent executory interest is nevertheless good under the Rule because the contingency is one which by its own terms must be resolved within the perpetui-

\footnotetext{
67 GRAY 191 .

${ }^{58} \mathrm{~A}$ gift to a class stands or falls as a unit. If the interest of any member of the class might vest remotely, the gift is bad in its entirety. Leake v. Robinson, 2 Mer. 363, 35 Eng. Rep. 979 (Ch. 1817). If $A$ bequeaths $\$ 100,000$ "to such of my lineal descendants as are alive twenty years after my [ $A$ 's] death," and "descendants" is construed to mean "descendants whenever born," the gift is good with respect to lineal descendants alive at $A$ 's death because they will survive the running of the twenty year period, or not, within their own lives. Although lineal descendants born after $A$ 's death will also survive the running of the twenty year period, or not, within their own lives, they are not persons in being at $A^{\prime}$ 's death. The validity of the gift to afterborn lineal descendants can be demonstrated only by pointing out that the contingency is one which must be resolved within the perpetuities period, namely within the period in gross of twenty-one years. Because the gift stands or falls as a unit, the method of demonstrating validity which saves the more vulnerable gift is used exclusively.

${ }^{60}$ See note 58 supra.
} 
ties period. The twenty-one year period may be in gross as well as connected with the minority of any person. ${ }^{80}$ The lineal descendants of $A$ who are alive at the end of the twenty-year period specified by $A$ are identifiable well within the period in gross of twenty-one years, and the gift is good under the Rule even though the ultimate recipients may include a person or persons unborn at $A$ 's death. If $A$ bequeaths $\$ 100,000$ "to such of my lineal descendants alive at my death as are alive twenty years after my death," the validity of the contingent executory interest under the Rule can be demonstrated either by using the lives of the donees or by pointing out that the contingency is one which by its own terms must be resolved within the permissible period.

Occasionally the life used to demonstrate the validity of a general testamentary or special power of appointment is that of the donee of the power. If $A$ bequeaths $\$ 100,000$ "to $T$ and his heirs, in trust, to pay the net income to $B$ for life, and then to pay the net income to such of the children of $B$, to one or more to the exclusion of the other or others, in such shares and proportions, and at such time or times, as $X$, and $X$ alone, shall select, and at the death of the survivor of the children of $B$, to pay the principal to $C$ and his heirs," and "children" is construed to mean "children of $B$ whenever born," the life of $X$ is used to demonstrate the validity of the special power of appointment. Because the power can be exercised by $X$ only and $X$ is alive at $A$ 's death, the power cannot be exercised beyond the perpetuities period. ${ }^{\text {11 }}$

If there is no condition of survivorship attached to the contingent gift and the contingency is one which by its own terms may be resolved beyond the perpetuities period, it may be impossible to demonstrate validity under the Rule. If $A$ devises "to $B$ and his heirs so long as the land is used for church purposes, then to $C$ and his heirs," the contingent executory interest is bad under the Rule. Neither the life of $B$ nor the life of $C$ is a relevant life. The void interest is stricken from the will. $B$ has a fee simple determinable, and the successor in interest of $A$ has a possibility of reverter by implication. ${ }^{62}$

The demonstration of validity of a contingent future interest

${ }^{\circ 0} 6$ A.L.P. $\$ 24.14 ; 3$ Simes \& SMITH $\$ 1225$. California has a sixty year period in gross. CaL. Civ. CODE ANN. $\$ 715.6$ (Supp. 1963).

${ }^{\circ 1} 6$ A.L.P. $\S 24.32 ; 3$ SiMES \& SMITH $\S 1272$.

${ }^{62} 6$ A.L.P. $\$ 24.47 ; 3$ SIMES \& SMITH $\S 1263$. 
under the Rule is ordinarily made as of the time the instrument of transfer takes effect, usually the delivery of a deed or the death of a testator. If a life otherwise relevant does not exist at the effective date of the instrument of transfer, a contingent future interest seemingly bad under the Rule may, on closer analysis, be good. If $A$ bequeaths $\$ 100,000$ "to $T$ and his heirs, in trust, to pay the net income to $B$ for life, then to pay the net income to the children of $B$ for their lives, and then to pay the principal to the grandchildren of $B$," and $B$ predeceases $A$, the bequest is the equivalent of "to $T$ and his heirs, in trust, to pay the net income to the children of $B$ (persons alive or conceived at $A$ 's death) for their lives, and then to pay the principal to the grandchildren of $B$." Even though "grandchildren of $B$ " is construed to mean "grandchildren of $B$ whenever born," the gift of principal is good under the Rule because any grandchild of $B$ born after $A$ 's death will be born within the lifetime of a child of $B$ alive at $A$ 's death (and an actual period of gestation). ${ }^{63}$

2. Demonstrating Validity Under "Wait and See" and Under "Wait and See" Coupled with Cy Pres

"Wait and see" allows a somewhat wider latitude with respect to choosing a life in being at the creation of the interest to demonstrate the validity of a contingent future interest under that version of the Rule. Coupling cy pres with "wait and see" may save a contingent future interest which is bad under the Rule in both orthodox and "wait and see" form. If $A$ devises "to $B$ for life, remainder to that son of $B$ who first attains twenty-five," and no son of $B$ has attained twenty-five at $A$ 's death and "son" is construed to mean "son whenever born," the contingent remainder is bad $a b$ initio under the Rule in orthodox form. Under "wait and see" alone, or "wait and see" coupled with cy pres, the contingent remainder is not neces-

${ }^{03} 6$ A.L.P. $\$ 24.25$. Conversely, if a relevant life does exist at the effective date of the instrument of transfer, a disposition prima facie troublesome is demonstrably good under the Rule. If $A$ bequeaths $\$ 100,000$ "to $T$ and his heirs, in trust, to pay the net income to $B$ for life, and then to pay the net income to such of the children of $B$, to one or more to the exclusion of other or others, and in such shares and proportions, and at such time or times, as the first-boru son of $C$ shall select, and at the death of the survivor of the children of $B$, to pay the principal to $C$ and his heirs," and $X$, the first-born son of $C$ is alive at $A$ 's death, the life of $X$ is used to demonstrate the validity of the special power of appointment if "children" is construed to mean "children of $B$ whenever born." Because the power can be exercised by $X$ only and $X$ is alive at $A$ 's death, the power cannot be exercised beyond the perpetuities period. 6 A.L.P. $§ 24.32 ; 3$ SIMEs \& SMITH $\$ 1272$. 
sarily bad $a b$ initio. Whether or not it is bad at its creation depends on facts existing at $A$ 's death. If there is nothing to "see" after $A$ 's death, one need not "wait," and a declaration of invalidity is per. missible at $A$ 's death. ${ }^{64}$ If not bad $a b$ initio, whether or not it is invalidated thereafter depends on the turn of events, as the following examples illustrate.

(1) If $B$ at $A$ 's death is childless and incapable of conceiving a child, or if all children of $B$ alive at $A$ 's death are females, and $B$ is incapable of conceiving further children at and after $A$ 's death, the contingent remainder is bad $a b$ initio under "wait and see," and a declaration of invalidity is permissible at $A$ 's death. Under "wait and see" coupled with cy pres, if $B$ at $A$ 's death is childless and incapable of conceiving a child, reformation is impossible, and a declaration of invalidity is permissible at $A$ 's death. If all children of $B$ alive at $A$ 's death are females, and $B$ is incapable of conceiving

${ }^{\text {B }}$ BrégX, INTESTATE, Wills ANd Estates Acts of 1947, at 5255 (1949) [hercinafter cited BRÉGY] appears to be contra, but Brégy should be read in the context of his examples. He says: "The only immediate effect [of the Pennsylvania Estates Act of 1947, § 4(a)-(b), now PA. STAT. ANN. tit. 20, § 301.4(a)-(b) (1950)] will be that no trust subject to this act will be stricken down in its entirety on the ground that it is impossible to separate the good estates from the bad.... As pointed out below, however, such-cases were becoming rare even under the old law. The tendency lias long been to uphold the valid life estates and postpone decision on remote remainders until the valid estates are terminated. The present act merely makes this practice mandatory in all cases governed by the act. Aside from this, the practicing attorncy is not likely to meet these sections in litigation for some timc." (Emphasis supplied.) But the hypothetical case put by Brégy is one in which the contingent remainder might vest within the perpetuities period as measured by actual events. Id. at 5254 . Refusing to declare a contingent future interest invalid uncler "wait and sec" on the ground that the perpetuities period has not yet run is under some circumstances just as absurd as declaring a contingent future interest invalid under the Rule in orthodox form on the ground that a fantastic possibility might become a reality. If $A$ devises "to $B$ for life, remainder to that son of $B$ who first attains twenty-five," and $B$ at $A$ 's death is childless and incapable of conceiving a child, the contingent remainder will necessarily fail by virtue of its own limitation. Under the Rule in orthodox form, it is improper to recognize the fact that no one can ever qualify for the gift in fact, and invalidity turns on the fantastic possibility that $B$ might have a son who might attain twenty-five at a remote time. Under "wait and sec," it is proper to recognize the fact that the contingent remainder will necessarily fatil by its own terms, and a court should not refuse a declaration of invalidity at $A$ 's death if $B$ and the reversioner wish to join in a salc of the land and marketability turns on securing the declaration. Section 5 (c) of the Pennsylvania Lstates Act of 1947 [now PA. STAT. ANN. tit. $20 \S 301.5$ (c) $(1950)$ ] is not decisive in the case put. It provides that "any other void interest [uncler the Rule] shall vest in the person or persons entitled to the income at the expiration of the ... [perpetuitics period]." The reversioner is entitled to the income at the expiration of the perpetuitics period. See BRÉGY at 5267. Because "wait and see" permits a declaration of the failure of an interest by its own terms on the basis of actualitics, a contingent future interest which cannot vest within the perpetuitics period because in fact it will fail by its own terms is said to be bad under "wait and sce.". 
further children at and after $A$ 's death, reformation may be requested at $A$ 's death. If reformation is refused, a declaration of invalidity is then permissible.

(2) If $B$ at $A$ 's death is childless but capable of conceiving a child, the contingent remainder is not bad $a b$ initio under "wait and see." If $B$ dies childless, the contingent remainder is bad under "wait and see" because it cannot vest within the perpetuities period, namely $B$ 's lifetime and twenty-one years. A declaration of invalidity is permissible when $B$ becomes incapable of conceiving a child or at $B$ 's death, whichever occurs first. If "wait and see" is coupled with cy pres, reformation is impossible.

(3) If all children of $B$ alive at $A$ 's death are females, and $B$ is capable of conceiving further children at and after $A$ 's death, the contingent remainder is not bad $a b$ initio under "wait and see." If $B$ dies without bearing or fathering a son, the contingent remainder is bad under "wait and see" because it cannot vest within the perpetuities period, namely $B$ 's lifetime and twenty-one years. A declaration of invalidity is permissible when $B$ becomes incapable of conceiving a child or at $B$ 's death, whichever occurs first. If "wait and see" is coupled with cy pres, reformation may be requested when $B$ becomes incapable of conceiving a child or at $B$ 's death, whichever occurs first. If reformation is refused, a declaration of invalidity is then permissible.

(4) If a son of $B$ alive at $A$ 's death has attained twenty-five at $B$ 's death, the contingent remainder is good under "wait and see" because it has vested within the lifetime of a person alive at $A$ 's death, namely the son himself. Under "wait and see" coupled with cy pres, no reformation is required.

(5) If a son of $B$ born after $A$ 's death has attained twenty-five at $B$ 's death, the contingent remainder is good under "wait and see" because it has vested within the lifetime of a person alive at $A$ 's death, namely $B$. Under "wait and see" coupled with cy pres, no reformation is required.

(6) If no son of $B$ has attained twenty-five at $B$ 's death, and $B$ dies survived by sons, one or more of whom were alive at $A$ 's death and one or more of whom were born after $A$ 's death, determination of the validity of the contingent remainder is deferred under "wait and see." 
(a) If a son of $B$ alive at $A$ 's death thereafter attains twentyfive, the contingent remainder is good under "wait and see" because it has vested within the lifetime of a person alive at $A$ 's death, namely the son himself.

(b) If no son of $B$ alive at $A$ 's death attains twenty-five, but the survivor of $B$ 's sons alive at $A$ 's death dies survived by a son or sons of $B$ born after $A$ 's death, one or more of whom are four or more years of age (but not twenty-five), determination of the validity of the contingent remainder is deferred under "wait and see."

(i) If a son of $B$ born after $A$ 's death attains twenty-five within twenty-one years after the death of $B$ and $B$ 's sons alive at $A$ 's death, the contingent remainder is good under "wait and see" because it has vested within the perpetuities period, namely the lives of $B$ and $B$ 's sons alive at $A$ 's death and twenty-one years.

(ii) If no son of $B$ attains twenty-five within the perpetuities period, the contingent remainder is bad under "wait and see."

(c) If no son of $B$ alive at $A$ 's death attains twenty-five, and the survivor of $B$ 's sons alive at $A$ 's death dies survived by a son or sons of $B$ born after $A$ 's death, none of whom is four or more years of age, it is then clear that the contingent remainder cannot vest within the perpetuities period, and a declaration of invalidity is permissible.

Disposition of case (6) under "wait and see" coupled with cy pres is based on two principles: first, deferring reformation until it is clear that the contingent remainder created by the testator cannot vest within the perpetuities period as measured by actual events, and second, reforming to prefer possible beneficiaries alive at the time of reformation unless unfairness results from excluding the successors of those who could have qualified as beneficiaries of the gift as reformed were they not already dead at the time of reformation. Deferring reformation as long as possible is consistent with the underlying justification for "wait and see," namely carrying out the intention of the donor unless he violates the Rule in fact. Reformation complements "wait and see"; it does not displace it. In case (6), so long as the contingent remainder might vest within the perpetuities period as measured by the lives of $B$ and $B$ 's sons 
alive at $A$ 's death and twenty-one years, reformation should be refused. If no son of $B$ alive at $A$ 's death attains twenty-five, and the survivor of such sons dies survived by a son or sons of $B$ born after $A$ 's death, none of whom is four or more years of age, it is then clear that the contingent remainder cannot vest within the perpetuities period. It is reformed to read "remainder to that son of $B$ who first attains twenty-five, provided, however, that when it is clear that the remainder cannot vest within the perpetuities period as measured by actual events, the remainder shall vest in that son of $B$ who thereafter first attains twenty-one." Such reformation does not assure vesting, for no son of $B$ may attain twenty-one after it is clear that the remainder as created by the testator cannot vest within the permissible period. If so, the contingent remainder as reformed fails by virtue of its own limitation.

\section{The Period in Gross Under "Wait and See" and Under "Wait} and See" Coupled with Cy Pres

If $A$ devises "to $B$ and his heirs so long as the land is used for church purposes, then to $C$ and his heirs," the contingent executory interest is bad under the Rule in orthodox form. The void interest is stricken from the will, and $B$ has a fee simple determinable. The successor in interest of $A$ has a possibility of reverter by implication. ${ }^{65}$ Under "wait and see," the contingent executory interest is not bad $a b$ initio. There being no relevant lives, the twenty-one year period in gross is used to test validity. If the use for church purposes ceases within twenty-one years after $A$ 's death, the contingent executory interest is transformed into a vested fee simple absolute, good under "wait and see." If the use for church purposes continues beyond twenty-one years after $A$ 's death, the contingent executory interest is bad even under "wait and see."66 The void interest is stricken from the will. The successor in interest of $A$ has a possibility of reverter by implication. The contingent executory interest is bad even under "wait and see" coupled with cy

\footnotetext{
${ }^{05} 6$ A.L.P. \$ 24.47; 3 SIMES \& SMITH \$ 1263. In California the executory interest in $C$ is vested under $\S 715.8$ of the Civil Code and therefore valid under the Rule. CAL. Crv. CODE ANN. $\S 715.8$ (Supp. 1963). However, the repeal of $\S 715.8$ has been demanded. Comment, California Revises the Rule Against Perpetuities-Again, 16 StAN. L. REv. 177, 190 (1963). See notes 13 supra, 131 infra.

${ }^{\circ 0}$ Leach, Perpetuities Legislation: Hail Pennsylvania! 108 U. PA. L. Rev. 1124, 1145 (1960). In Pennsylvania the void interest vests in $B$. PA. Stat. Ann. tit. 20, $\S$ 301.5 (b) (1950).
} 
pres, for there is no practicable method of reforming it to save it from invalidity. The life of neither $B$ nor $C$ has a "causal relationship to the vesting or failure of the interest," ${ }^{17}$ and the cy pres feature of the Kentucky perpetuities statute requires reformation "within the limits of [the Rule Against Perpetuities] as... modified" 68 by "wait and see," including implicit limitations on the lives that may properly be used as measuring lives. Even so, the executory interest following a fee simple determinable which remains contingent at the end of the twenty-one year period in gross is not bad in Kentucky because the Rule Against Perpetuities there has been both superseded and complemented by two statutes:

The estate known at common law as the fee simple determinable and the interest known as the possibility of reverter are abolished. Words which at common law would create a fee simple determinable shall be construed to create a fee simple subject to a right of entry for condition broken. In any case where a person would have a possibility of reverter at common law, he shall have a right of entry. ${ }^{60}$

A fee simple subject to a right of entry for condition broken shall become a fee simple absolute if the specified contingency does not occur within thirty years from the effective date of the instrument creating such fee simple subject to a right of entry. If such contingency occurs within said thirty years the right of entry, which may be created in a person other than the person creating the interest or his heirs, shall become exercisable notwithstanding the rule against perpetuities....70 (Emphasis supphied.)

Therefore, if $A$ devises "to $B$ and his heirs so long as the land is used for church purposes, then to $C$ and his heirs," $B$ in Kentucky has a fee simple subject to a right of entry for condition broken in $G$. If the use of the land for church purposes ceases within thirty years after $A$ 's death, $C$ 's right of entry for condition broken is transformed into a fee simple absolute. If the use of the land for church purposes continues beyond thirty years after $A$ 's death, the fee simple in $B$ becomes absolute. Vermont, which has a "wait and see" version of the Rule coupled with cy pres, has no counterpart of the Kentucky statutes which supersede and complement the Rule.

\footnotetext{
${ }^{67}$ Kx. Rev. Stat. ANn. § 381.216 (1963).

${ }^{68}$ Ibid.

${ }^{69}$ Ky. Rev. Stat. ANN. $\$ 381.218$ (1963).

${ }^{70}$ Ky. Rev. Stat. ANN. \$ 381.219 (1963).
} 


\section{V}

Construction and the Rule-Fantastic Possibilities

\section{A. Fantastic Possibilities Under}

the Rule in Orthodox Form

Although the existence of the common law Rule Against Perpetuities unquestionably affects the construction by courts of limitations in deeds, wills, and trusts, the Rule is not a rule of construction; it is a rule of law which applies irrespective of the intention of the donor. ${ }^{71}$ Gray asserts that "every provision in a will or [deed] is to be construed as if the Rule did not exist, and then to the provision so construed the Rule is to be remorselessly applied."72 Whatever the prevalence Gray's notion formerly attained, remorseless application is not the practice today; but the factors which motivate a court to avoid a construction leading to invalidity under the Rule are unindexed. Syntactical and historical considerations play a part, and they ought not to be overlooked by either the draftsman inviting a preferred construction or the litigant seeking an advantageous interpretation of a dispositive instrument. Courts write of using a technique which carries out the intention of the grantor or testator or which avoids an intestacy. They may be influenced by such factors as the identity of the competing claimants, the amount at stake, the probability that events will occur in the sequence commonly encountered, the actual turn of events in the interval between the time the instrument of transfer takes effect and the time litigation begins, and the prestige and persuasiveness of the authority to whom they turn for guidance..$^{73}$

The area of freedom given to the courts by the rules of construction is great, and they resist resting a decision solely on classification of interests. Although the hypothetical cases posed in this article are prototypes to which it is frequently almost impossible to assimilate the half-articulated expressions of the grantor or testator, consider the freedom inherent in the prototypes themselves:

(l) $A$ devises "to $B$ for life, then to $B$ 's children for their lives, remainder to the grandchildren of $B . " B$ is a woman eighty years old at execution of the will. If "grandchildren" is construed to

\footnotetext{
${ }^{71}$ GRAY 599.

73 Ibid.

${ }^{73}$ Second Bank-State St. Trust Co. v. Second Bank-State St. Trust Co., 335 Mass. 407, 140 N.E.2d 201 (1957).
} 
mean "grandchildren of $B$ alive at $A$ 's death," the gift to grandchildren is unaffected by the Rule because it is an indefeasibly vested remainder. ${ }^{74}$ Even if "grandchildren" is construed to mean "grandchildren whenever born," the gift to grandchildren is good under the Rule if "grandchildren whenever born" is further construed to mean "grandchildren whenever born to children of $B$ who predeceased $A$ or were alive at $A$ 's death" because the ultimate number of grandchildren sharing in the gift will be known at the end of lives in being at $A$ 's death, namely at the death of the survivor of $B$ 's children.75 But if "children" is construed to mean "children of $B$ whenever born" and "grandchildren" is construed to mean "grandchildren of $B$ whenever and to whomever born," the gift to grandchildren is bad under the Rule because the ultimate number of grandchildren sharing in the gift might not be known until the death of a person unborn at $A$ 's death, namely an afterborn child of $B$. Leach has dubbed this the "fertile octogenarian" case. ${ }^{70}$

(2) $A$ devises "to $B$ for life, remainder to such of $B$ 's grandchildren living at my death or born within five years thereafter as attain twenty-one." If "grandchildren" is construed to mean "grandchildren of $B$ whose parent or parents (a child or children of $B$ ) are alive at $A$ 's death," the gift to grandchildren of $B$ is good under the Rule because the ultimate number of grandchildren sharing in the gift will be known at the latest at the end of lives in being at $A$ 's death and twenty-one years. But if "grandchildren" is construed to mean "grandchildren of $B$ whose parent or parents (a child or children of $B$ ) are born at any time," the gift to grandchildren is bad under the Rule. $B$ might have another child after $A$ 's death who might marry and have a child within five years of $A$ 's death. This unborn child of $B$ 's unborn child might attain twenty-one and qualify to share in the remainder. Therefore the ultimate number of grandchildren sharing in the gift might not be known until

\footnotetext{
743 SIMES \& SMITTH $\S 1235$.

${ }^{\pi 5} 6$ A.L.P. $\$ 24.22$.

${ }^{78}$ Ibid. The gift of income "to $B$ 's children for their lives" is ordinarily construed to mean "to $B$ 's children for their lives, whenever born, with cross remainders." 2 SIMEs \& SMITH $\S 843$. The gift vests at $A$ 's death in children of $B$ then alive, subject to open to allow afterborn children of $B$ to share. The gift of income to $B$ 's children is good under the Rule because it vests in every respect no later than at $B^{\prime}$ s death. Because all cross remainders vest no later than at $B^{\prime} s$ death, it is irrelevant that the proportionate part of the income received by a child of $B$ might change beyond the perpetuities period. (The last to die of the children of $B$ alive at $A$ 's death might die survived by children of $B$ born after $A$ 's death.)
} 
twenty-one years after the birth of a child to an afterborn child of $B$. Leach calls this the "precocious toddler" case. ${ }^{77}$

(3) $A$ devises "to $B$ for life, then to $B$ 's widow for life, remainder to such of the children of $B$ as survive the survivor of $B$ and $B$ 's widow." If "children" is construed to mean "children of $B$ alive at $A$ 's death" who survive the survivor of $B$ and $B$ 's widow, the gift to children is good under the Rule because children of $B$ alive at $A$ 's death will survive the survivor of $B$ and $B$ 's widow, or not, within their own lives, regardless of when $B$ 's widow is born. If "widow" is construed to mean "that woman who is $B$ 's wife at $A$ 's death," the gift to the children is good under the Rule irrespective of whether "children" is construed to mean "children of $B$ alive at $A$ 's death" or "children of $B$ whenever born," because identification of the children who qualify to share in the gift will be made at the end of a life in being at $A$ 's death. But if "children" is construed to mean "children of $B$ whenever born" and "widow" is construed to mean "that wife of $B$, whenever born, who survives $B$," the gift to children is bad under the Rule because identification of the children who qualify to share in the gift might be deferred until the death of a person unborn at $A$ 's death, namely the "unborn widow."78

(4) $A$ devises "to such of my lineal descendants as are alive at the probate of my will." If "descendants" is construed to mean "decendants alive at $A$ 's death" who survive to probate, the gift to descendants is good under the Rule because descendants of $A$ alive at his death will survive to probate, or not, within their own lives, regardless of when probate occurs. If the evidence shows that probate normally occurs well within the period in gross of twentyone years, the gift to descendants is good under the Rule irrespective of whether "descendants" is construed to mean "descendants alive at $A$ 's death" or "descendants whenever born," because "at the probate of my will" is then construed to mean "at the probate of my will provided probate occurs well within the period in gross of twenty-one years." But if "descendants" is construed to mean "descendants whenever born" and it is assumed that probate might occur at any time, the gift to descendants is bad under the Rule because identification of the descendants who qualify to share in

\footnotetext{
${ }^{77} 6$ A.L.P. $\$ 24.22$.
}

${ }^{78} I d . \S 24.21$. 
the gift might be deferred beyond the perpetuities period. This is the "administration contingency" case..$^{79}$

B. Fantastic Possibilities Under "Wait and See" and Under "Wait and See" Coupled with Cy Pres

That the actualities test for validity of a contingent future interest under the "wait and see" version of the Rule is the antithesis of the possibilities test can be shown through a reconsideration of the "fertile octogenarian" case. If $A$ devises "to $B$ for life, then to $B$ 's children for their lives, remainder to the grandchildren of $B$," and "children" is construed to mean "children of $B$ whenever born" and "grandchildren" is construed to mean "grandchildren of $B$ whenever and to whomever born," the gift to grandchildren is bad under the Rule in orthodox form because the ultimate number of grandchildren sharing in the gift might not be known until the death of a person unborn at $A$ 's death, namely an afterborn child of $B$. The gift to grandchildren is bad although $B$ is a woman eighty years old at $A$ 's death. The gift to grandchildren is bad although $B$ is a woman eighty years old at execution of the will. Under "wait and see" the gift to grandchildren is good even though "grandchildren" is construed to mean "grandchildren of $B$ whenever and to whomever born." A woman eighty years old at the execution of the will or at $A$ 's death is incapable of conceiving a child after $A$ 's death. Under the circumstances, "grandchildren" in fact means "children born to children of $B$ who predeceased $A$ or were alive at $A$ 's death." A grandchild of $B$ born after $A$ 's death will be conceived by a child of $B$ alive at $A$ 's death. Therefore the ultimate number of grandchildren sharing in the gift will be known at the latest at the death of a child of $B$ alive at $A$ 's death. The same analysis applies if $B$ is for any reason incapable of conceiving a child after $A$ 's death. If "wait and see" is coupled with cy pres, no reformation is required. ${ }^{80}$

Determination of the validity of a contingent future interest under "wait and see" may be made as of the time the interest is created. If $A$ devises "to $B$ for life, then to $B$ 's children for their lives, remainder to the grandchildren of $B$," and "grandchildren" is construed to mean "grandchildren of $B$ whenever and to whomever born," it is possible to demonstrate the validity of the gift to the

\footnotetext{
${ }^{70} \mathrm{Id}$. $\$ 24.23$.
}

${ }^{80}$ DUKEMINIER 86. 
grandchildren at $A$ 's death if $B$ is for any reason incapable of conceiving a child after $A$ 's death. But determination of validity may be deferred under "wait and see" to a time beyond $A$ 's death.

(I) If $B$, although capable of conceiving a child after $A$ 's death, dies without having a child after $A$ 's death, the gift to grandchildren is good under "wait and see" because the ultimate number of grandchildren sharing in the gift will be known at the latest at the death of a child of $B$ alive at $A$ 's death. Validity of the gift to grandchildren can be demonstrated at $B$ 's death or at the time $B$ for any reason becomes incapable of conceiving a child. If "wait and see" is coupled with cy pres, no reformation is required. ${ }^{81}$

(2) If $B$, capable of conceiving a child after $A$ 's death, dies survived by a child born after $A$ 's death, the validity of the gift to grandchildren cannot be demonstrated at $B$ 's death because the ultimate number of grandchildren sharing in the gift might not be known until the death of such afterborn child of $B$. If such afterborn child of $B$ predeceases a child or children of $B$ alive at $A$ 's death, the gift to grandchildren is good under "wait and see" because the ultimate number of grandchildren sharing in the gift will be known at the latest at the death of a child of $B$ alive at $A$ 's death. Validity of the gift to grandchildren can be demonstrated at the death of such afterborn child of $B$. If "wait and see" is coupled with cy pres, no reformation is required. ${ }^{82}$

(3) If such afterborn child of $B$ is the survivor of $B$ 's children, the validity of the gift to grandchildren cannot be demonstrated at the death of the survivor of $B$ 's children alive at $A$ 's death because the afterborn child of $B$ might have a child later than twenty-one years after the death of the survivor of $B$ 's children alive at $A$ 's death. ${ }^{83}$

(a) If the afterborn child of $B$ dies within twenty-one years after the death of the survivor of $B$ 's children alive at $A$ 's death, the gift to grandchildren is good under "wait and see" because the ultimate number of grandchildren sharing in the gift is fixed within the permissible period, namely the lives of $B$ and $B$ 's children alive at $A$ 's death and twenty-one years. ${ }^{84}$ Validity of the gift to grandchildren can be demon-

\footnotetext{
${ }^{81}$ Ibid.

82 Ibid.

${ }^{33}$ BRtG 5278; DUKEMINIER 87.

Bt BRÉGY 5278.
} 
strated at the death of $B$ 's afterborn child. If "wait and see" is coupled with cy pres, no reformation is required. ${ }^{85}$

(b) If all children born to the afterborn child of $B$ are in fact born no later than twenty-one years after the death of the survivor of $B$ 's children alive at $A$ 's death, the gift to grandchildren is good under "wait and see" because the ultimate number of grandchildren sharing in the gift is in fact fixed within the permissible period, namely the lives of $B$ and $B$ 's children alive at $A$ 's death and twenty-one years. Validity of the gift to grandchildren can be demonstrated at the death of $B$ 's afterborn child or at that earliest point in time beyond

${ }^{85}$ Dukeminier says that "if all...[B's] children in being at ... [the testator's] death die, survived by a child of ... [B] not in being [at the testator's death], it will then be known that the remainder [to grandchildren of $B]$ is incapable of vesting within lives in being. The will is then reformed ... to vest the gift within twenty-one years of the death of $\ldots\left[B^{\prime}\right.$ 's] children in being at... [the testator's] death." (Emphasis supplied.) Dukeminier 87. If the gift to $B$ 's children is construed to mean "to $B$ 's children for their lives, with cross remainders," the survivor of $B$ 's children is entitled to a life tenancy with respect to the entire fee simple. 2 SIMES \& SMrTH $\S 843$. No distribution of the remainder being called for until the death of the survivor of $B$ 's children, irrespective of when such survivor was born, there appears to be no compelling reason to reform the will until either (1) twentyone years have elapsed after the death of the survivor of $B$ 's children alive at $A^{\prime}$ 's death, (2) the afterborn child of $B$ for any reason becomes incapable of conceiving a child, or (3) the afterborn child of $B$ dies, whichever event occurs first. For at that point in time, and not before, the ultimate number of grandchildren sharing in the remainder is determinable. In short, reformation might occur at the death of the survivor of $B$ 's children alive at $A$ 's death, but it might properly be deferred until a later time if indeed it occurs at all. The words "within the limits of that rule" in the Kentucky reform statute of 1960, KY. REv. STAT. ANN. § 381.216 (1963), do not appear to affect the matter. See note 86 infra.

To determine the time of reformation in a jurisdiction having modified or limited "wait and see" coupled with cy pres, consult the language of the statute and authoritative interpretation. The relevant provisions of the Massachusetts statute are as follows: "In applying the rule against perpetuities to an interest in real or personal property limited to take effect at or after the termination of one or more life estates in, or lives of, persons in being when the period of said rule commences to run, the validity of the interest shall be determined on the basis of facts axisting at the termination of such one or more life estates or lives. In this section an interest which must terminate not later than the death of one or more persons is a life estate' even though it may terminate at an earlier time. (Emphasis supplied.)

"If an interest in real or personal property would violate the rule against perpetuities as modified by section one because such interest is contingent upon any person attaining or failing to attain an age in excess of twenty-one, the age contingency shall be reduced to twenty-one as to all persons subject to the same age contingency." MASs. LAwS ANN. ch. 184A, $\S \S 1,2$ (1955). These two sections of the Massachusetts statute were adopted verbatim in Connecticut, Maine, and Maryland. Conn. Gen. Stat. Ann. \$§ 45-95, -96 (1960); ME. Rev. Stat. AnN. ch. 160, \$§ 27, 28 (Supp. 1963); Mo. ANN. CoDE art. 16, § 197A (Supp. 1963). For interpretation, sce Leach, Perpetuities Legislation, Massachusetts Style, 67 HARv. L. REv. 1349, 1357, 1360 (1954). 
the permissible period when the afterborn child of $B$ for any reason becomes incapable of conceiving a child. If "wait and see" is coupled with cy pres, no reformation is required. ${ }^{86}$

(c) If a child is born to the afterborn child of $B$ later than twenty-one years after the death of the survivor of the children of $B$ alive at $A$ 's death, the gift to grandchildren is bad under "wait and see" because the ultimate number of grandchildren sharing in the gift is not fixed within the permissible period. If "wait and see" is coupled with cy pres, the gift to grandchildren is reformed to read "remainder to the grandchildren of $B$ alive at my $[A$ 's] death and born within a period measured by the lives of $B$ and $B$ 's children alive at my death and twenty-one years."st

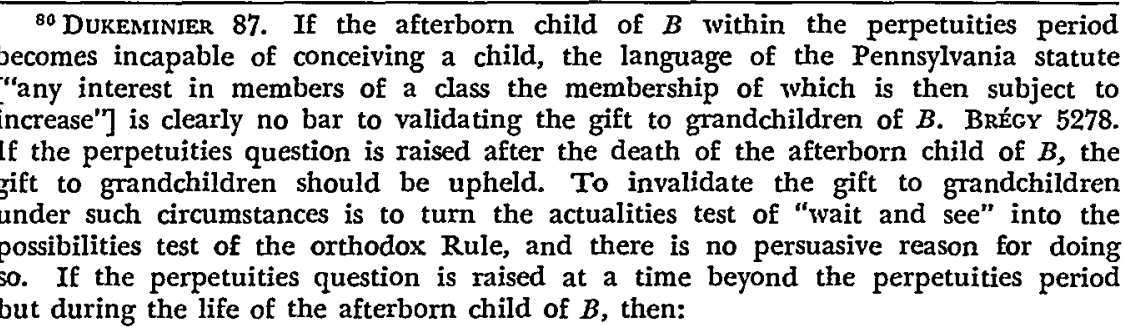

(a) the gift to grandchildren should be upheld if the afterborn child of $B$ is incapable of conceiving a child.

(b) the perpetuities question should be deferred in Pennsylvania if the afterborn child of $B$ is capable of conceiving a child. Brégy appears to say that the gift to grandchildren is bad. BRÉcY 5266, 5278. Under "wait and see" coupled with cy pres, reformation is permissible. See note 85 supra.

To the argument that the construction here preferred makes superfluous the allusion of the Pennsylvania statute to class gifts, there is an answer: the language of the statute assures that the class gift will not be split to permit gifts to grandchildren which are in themselves good under the Rule to take effect when gifts to actual grandchildren which are in themselves bad are invalidated even under "wait and see." The statute requires that the gift to grandchildren stand or fall as a unit. Although it could be construed to require more, it need not be so construed with respect to the case posed in the text. $\$ 5$ (c) of the Pennsylvania Estates Act of 1947 [now PA. Stat. ANN. tit. 20, $\$ 301.5$ (c) (1950)] is relevant here, because the afterborn child of $B$ takes if the gift to grandchildren is bad. It is not decisive. See note 64 supra.

${ }^{87}$ Dukeminier 87. The same approach is used to the "unborn widow" case. $A$ devises "to $B$ for life, then to $B$ 's widow for life, remainder to such of the children of $B$ as survive the survivor of $B$ and $B$ 's widow." Assume that "widow" is construed to mean "that wife of $B$, whenever born, who survives $B$ " and "children" is construed to mean "children of $B$ whenever born." If $B$ dies survived by an unborn widow and one or more children, all of whom were alive at $A$ 's death, the contingent remainder to the children of $B$ is good under "wait and see" because it will vest, if at all, within the lives of children of $B$ alive at $A$ 's death. If $B$ dies survived by a widow alive at $A$ 's death and children, one or more of whom were born after $A$ 's death, the contingent remainder to the children of $B$ is good under "wait and see" because it will vest, if at all, within the lifetime of $B$ 's widow, a person alive at $A$ 's 


\section{VI \\ Glass Gifts \\ A. Class Gifts Under the Rule in Orthodox Form}

Casner says that a gift is to a class "when the beneficiaries of a disposition form an entity or a unit and the gift is to that entity or unit rather than to the separate and distinct individuals who comprise the entity or unit."s8 A gift to a class is totally invalid under the common law Rule Against Perpetuities unless the ultimate number of persons sharing in the gift (or the ultimate size of the shares) is determinable within the perpetuities period. ${ }^{80}$ A gift to a class stands or falls as a unit. If the interest of any member of the class might vest remotely, the class gift fails entirely. If $A$ devises "to $B$ for life, remainder to such of the children of $B$ as attain twentyfive," and "children" is construed to mean "children of $B$ alive at $A$ 's death," the gift to children is good under the Rule because the ultimate number of children of $B$ who attain twenty-five and share

death. If $B$ dies survived by an unborn widow and children, one or more of whom were born after $A$ 's death, determination of validity is deferred:

(I) If $B$ 's widow dies survived by children of $B$ of whom at least one was alive at $A$ 's death, the contingent remainder to the children of $B$ is good under "wait and see" and vests at the death of the unborn widow.

(2) If $B$ 's widow dies within twenty-one years after the death of $B$ and all of $B$ 's children alive at $A$ 's death, survived by a child or children of $B$, the contingent remainder to tbe children of $B$ is good under "wait and see" and vests at the death of the unborn widow.

(3) If $B$ 's widow dies beyond twenty-one years after the death of $B$ and all of $B$ 's children alive at $A$ 's death, the contingent remainder to the children of $B$ cannot vest within the perpetuities period and is bad under "wait and see." If "wait and see" is coupled with cy pres, the gift to children is reformed to read "remainder to such of the children of $B$ as survive the survivor of $B$ and $B$ 's widow, provided, however, that if the remainder has not already indefeasibly vested twenty-one years after the death of $B$ and $B$ 's children alive at my [A's] death, it shall then indefensibly vest in such of $B$ 's children as are then alive."

(4) If $B$ 's widow dies beyond twenty-one years after the death of $B$ and all of $B$ 's children alive at $A$ 's death, and all of $B$ 's children are dead twenty-one years after the death of $B$ and all of $B$ 's children alive at $A$ 's death, the contingent remainder to the children of $B$ fails by virtue of its own limitation.

The reformation suggested in (3) above pushes the outer limits of the perpetuities Jperiod as far as "wait and see" permits. If it is thought preferable to try to save the contingent remainder from failure by virtue of its own limitation by shortening the period which is permissible under "wait and sec," reformation might take this form: "remainder to such of the children of $B$ as survive the survivor of $B$ and $B$ 's widow, provided, however, that if the remainder has not already indefeasibly vested twenty-one years after the death of $B$ [as opposed to "twenty-one yenrs after the death of $B$ and $B$ 's children alive at my ( $A$ 's) death"], it shall then indefeasibly vest in such of $B$ 's children as are then alive."

885 A.L.P. \& 22.4 .

${ }^{80}$ Leake v. Robinson, 2 Mcr. 363, 35 Eng. Rep. 979 (Ch. 1817). 
in the gift will be known within lives in being at $A$ 's death, namely children of $B$ alive at $A$ 's death. But if "children" is construed to mean "children of $B$ whenever born," the gift to children is bad under the Rule because a child might be born to $B$ after $A$ 's death and less than four years before $B$ 's death. Such afterborn child of $B$ might attain twenty-five later than twenty-one years after $B$ 's death. Although children of $B$ alive at $A$ 's death will attain twenty-five, or not, within their own lives (so that the gift to them is in itself good under the Rule), the fact that an afterborn child of $B$ might attain twenty-five beyond the perpetuities period makes the gift to children fail entirely under the Rule, because the ultimate number of children of $B$ sharing in the gift might be determined remotely..$^{90}$

The harsh effects of the "all-or-nothing" rule of Leake v. Robinson $^{91}$ are mitigated by the operation of the class closing rules, ${ }^{92}$ the exceptions of Cattlin v. Brown ${ }^{93}$ and Storrs $v$. Benbow, ${ }^{94}$ and the application of cy pres.

The operation of the class closing rules may preclude a violation of the common law Rule Against Perpetuities. That a class closes at a particular time means that no person born after that time can share in the gift.95 If $A$ bequeaths $\$ 100,000$ "to such of the children of $B$ as attain twenty-five," and no child of $B$ has attained twenty-five at $A$ 's death and "children" is construed to mean "children of $B$ whenever born," the bequest is bad under the Rule because the only children of $B$ to attain twenty-five might be children of $B$ who are unborn at $A$ 's death. However, if a child of $B$ has attained twentyfive at $A$ 's death, he is entitled under the "rule of convenience" to call for an immediate distribution to him of a minimum share.96 Afterborn children of $B$ then are not members of the class and cannot share in the bequest. All children of $B$ alive at $A$ 's death will attain twenty-five, or not, within their own lives, and there is no violation of the Rule.97

If $A$ bequeaths $\$ 100,000$ "to such of the children of $B$ as attain

\footnotetext{
Do 3 SIMES \& SMITH $\$ 1265$.

01 2 Mer. 363, 35 Eng. Rep. 979 (Ch. 1817).

Q2 Morris \& Leach, The Rule Against Perpetuities 109 (2d ed. 1962) [hereinafter cited as Morris \& LEACH].

${ }^{03} 11$ Hare 372, 68 Eng. Rep. 1319 (Ch. 1853).

042 My. \& K. 46, 39 Eng. Rep. 862 (Ch. 1833).

do Gulliver, Cases on Future INTERESTS 84 (1959).

${ }^{\circ 0} \mathrm{Id}$. at 85 .

${ }^{07}$ Morris \& Leach 113; 3 Simes \& SMith $\$ 1270$.
} 
twenty-five," and no child of $B$ has attained twenty-five but "children" is construed to mean "children of $B$ alive at $A$ 's death," the bequest is good under the Rule because all children of $B$ alive at $A$ 's death will attain twenty-five, or not, within their own lives. "Children" might be construed to mean "children of $B$ alive at $A$ 's death" because $B$ is a woman past menopause at the execution of the will. However, if "children" is construed to mean "children of $B$ whenever born," the bequest is bad under the Rule even though there are children of $B$ alive at $A$ 's death who will attain twentyfive, or not, within their own lives. 98 Under the "all-or-nothing" rule of Leake $v$. Robinson, ${ }^{99}$ a gift to a class stands or falls as a unit. If the interest of any member of the class might vest remotely, the gift to the entire class is void. All children of $B$ alive at $A$ 's deatl might die without attaining twenty-five, and the first child of $B$ to attain twenty-five might do so later than twenty-one years after the death of $B$, the only relevant life in being at the creation of the interest under the Rule in orthodox form. When such afterborn child of $B$ had attained twenty-five, the ultimate number of children sharing in the gift still might not be known, because other afterborn children of $B$ who were members of the class might attain twentyfive. Put shortly, the bequest is bad under the Rule because the ultimate number of children sharing in the gift might be fixed beyond the perpetuities period. ${ }^{100}$

If $A$ devises "to $B$ for life, then to $B$ 's children for their lives, remainder to the grandchildren of $B$," and "grandchildren" is construed to mean "grandchildren of $B$ irrespective of when their parent or parents (a child or children of $B$ ) are born," the gift to grandchildren is bad under the Rule because a child might be born to $B$ after $A$ 's death, and the ultimate number of grandchildren sharing in the gift might not be determinable until the death of a person

\footnotetext{
${ }^{08} 3$ SIMES \& SMITH \& 1270. Contra, MORRIS \& LEAGH 113.

${ }^{89} 2$ Mer. 363 , 35 Eng. Rep. 979 (Ch. 1817).

${ }^{100}$ Analytically, a bequest of $\$ 100,000$ "to such of the children of $B$ as attain twenty-five" (no child of $B$ having attained twenty-five at the testator's death) is the same as a devise "to $B$ for life, remainder to such of the children of $B$ as attain twenty-five" ("children" being construed to mean "children of $B$ whenever born" in both cases). In the former case, the class is open beyond the testator's death because no one qualifies at the testator's death for a share of the bequest. In the latter case, the class is open at the testator's death because the existence of the life tenancy precludes calling for a distribution of the remainder; the class is open at the testator's death even though a child or children of $B$ have attained twenty-five at the testator's death.
} 
unborn at $A$ 's death, namely such afterborn child of $B .^{101}$ However, if there is a gift to a class of subclasses, the gift to a particular subclass is valid under the rule of Cattlin $v$. Brown, ${ }^{102}$ even though the gift to another subclass is remote. If $A$ bequeaths $\$ 100,000$ "to $T$ and his heirs, in trust, to pay the net income to $B$ for life, then to pay the net income to the children of $B$ for their lives, and upon the death of a child of $B$, to pay the principal upon which such child was receiving the income to the children of such deceased child of $B$," and "children of $B$ " is construed to mean "children of $B$ whenever born," the gifts of principal are good under the Rule with respect to grandchildren of $B$ whose parent or parents (a child or children of $B$ ) are alive at $A$ 's death but bad under the Rule with respect to grandchildren of $B$ whose parent or parents (a child or children of $B$ ) are born after $A$ 's death. The number of shares of principal represented by children of $B$ who survive $B$ will be known at the death of $B$, a person alive at $A$ 's death. The identification of grandchildren of $B$ sharing in principal represented by a child of $B$ alive at $A$ 's death will be made at the death of such child of $B$. The gifts of principal which are remote are separated from gifts of principal which are in themselves valid, and the latter are permitted to stand. ${ }^{103}$

If there is a gift of a specific sum to each member of a class (as differentiated from a gift of a fund to be divided among the class), the gifts to some members of the class are valid under the rule of Storrs $v$. Benbow, ${ }^{104}$ even though the gifts to other members of the class are remote. If $A$ bequeaths " $\$ 100$ each to such of the children

\footnotetext{
${ }^{101} 6$ A.L.P. $\$ 24.22$.

${ }^{102} 11$ Hare 372, 68 Eng. Rep. 1319 (Ch. 1853).

${ }^{103} 6$ A.L.P. $\$ 24.29 ; 3$ SIMEs \& SMITH $\$ 1267$. The rule of Cattlin $v$. Brown is not confined to the precise kind of limitation set out in the text. If $A$ bequeaths $\$ 100,000$ "to $T$ and his lieirs, in trust, to pay the net income to $B$ for life, then to pay the net income to the children of $B$ for their lives, with cross remainders, and on the death of the survivor of the children of $B$, to divide the principal into as many shares as there are children of $B$ who survive $B$, and then to pay the share of principal represented by a child of $B$ who survived $B$ to the children of such deceased child of $B$, " and "children of $B$ " is construed to mean "children of $B$ whenever born," the gifts of principal are good under the Rule with respect to grandchildren of $B$ whose parent or parents (a child or children of $B$ ) are alive at $A$ 's death. The gifts of principal are bad under the Rule with respect to grandchildren of $B$ whose parent or parents (a child or children of $B$ ) were unborn at $A$ 's death. A share of principal represented by a child of $B$ alive at $A$ 's death vests indefeasibly in the children of such child of $B$ when such child of $B$ dies. Once the remainder has indefeasibly vested, it is irrelevant that possession is postponed.

${ }_{104} 2$ My. \& K. 46, 39 Eng. Rep. 862 (Ch. 1833).
} 
of $B$ as attain twenty-five," and "children" is construed to mean "children of $B$ alive at $A$ 's death," the gifts to children are good under the Rule because all children of $B$ alive at $A$ 's death will attain twenty-five, or not, within their own lives. However, if "children" is construed to mean "children of $B$ whenever born," the gifts to children of $B$ alive at $A$ 's death are in themselves good under the Rule, but the gifts to afterborn children of $B$ are bad under the Rule because an afterborn child of $B$ might attain twentyfive beyond the perpetuities period. The gifts of a specific sum which are remote are separated from the gifts of a specific sum which are valid, and the latter are permitted to stand. ${ }^{105}$

Cy pres is a rule for the construction of an instrument in equity by which the intention of the donor is carried out as nearly as possible when it is impossible or illegal to give it literal effect. ${ }^{100}$ If $A$ bequeaths $\$ 100,000$ "to such of the children of $B$ as attain twenty-five," and no child of $B$ has attained twenty-five at $A$ 's death and "children" is construed to mean "children of $B$ whenever born," the bequest is good under the Rule if the court uses cy pres to reduce the age contingency from twenty-five to twenty-one. All children of $B$, including afterborn children, will attain twenty-one, or not, within twenty-one years after $B$ 's death. ${ }^{107}$ Reducing the age con-

\footnotetext{
${ }^{105} 6$ A.I.P. $\$ 24.28 ; 3$ SIMES \& SMITH $\$ 1266$.

${ }^{100} 4$ ScoTr, TRUSTS $\$ 399$ (2d ed. 1956).

${ }^{107}$ Carter v. Berry, 243 Miss. 321, 136 So. 2d 871, 140 So. 2d 843 (1962); Edgerly v. Barker, 66 N.H. 434, 31 Atl. 900 (1891). The sweeping cy pres feature of the recent modifications of the Rule in California has been given law review endorsement. Comment, California Revises the Rule Against Perpetuities-Again, 16 STAN. L. REv. 177, 186 (1963). Professor Browder prefers cy pres to "wait and see" or a combination of "wait and see" and cy pres. Browder, Construction, Reformation, and the Rule Against Perpetuities, 62 Micr. L. REv. 1 (1963). Some of the logical consequences of "wait and see" are implicit in cy pres. If $A$ devises "to $B$ for life, remainder to that son of $B$ who first attains twenty-five," and $B$ at $A$ 's death is childless and incapable of conceiving a child, the contingent remainder is bad at $A^{\prime}$ 's death under the Rule in both orthodox and "wait and see" form, and a declaration of invalidity is permissible at $A$ 's death. See note 64 supra. Under cy pres alone, re. formation would be futile because the contingent remainder, reformed to read "remainder to that son of $B$ who first attains twenty-one" would necessarily fail by its own terms. If $B$ and the reversioner wish to join in a sale of the land at $A$ 's death and marketability turns on securing a declaration of invalidity, a court should declare that the contingent remainder is bad under cy pres. The evidentiary problems raised are beyond the scope of this article, but they are not insurmountable. Leach, Perpetuities: New Hampshire Defertilizes the Octogenarians, 77 Harv. L. Rev. 279 (1963). A declaration of invalidity is permissible at $A$ 's death under cy pres because the contingent remainder created by the testator was bad $a b$ initio under the Rule in orthodox form, and it could have been declared bad at $A$ 's death. Nothing less than a comparable declaration is satisfactory under cy pres if cy pres is to improve the Rule Against Perpetuities.
} 
tingency to preclude a violation of the Rule enlarges the testator's gift because a child of $B$ who cannot qualify to share in the gift in its original form because he fails to attain twenty-five can qualify to share for the gift as modified if he attains twenty-one. Put shortly, a gift at twenty-five is included in a gift at twenty-one, but a gift at twenty-one is not included in a gift at twenty-five. ${ }^{108}$

B. Class Gifts Under "Wait and See" and Under "Wait and See" Coupled with Cy Pres

$A$ devises "to $B$ for life, remainder to such of the children of $B$ as attain twenty-five." "Children" is construed to mean "children of $B$ whenever born." $B$ is capable of conceiving a child after $A$ 's death. The validity of the gift to children cannot be demonstrated at $A$ 's death, and determination of validity is deferred.

(1) $B$ dies survived by children, one or more of whom have not attained twenty-five, but all of whom are more than four years of age. The gift to children of $B$ is good under "wait and see" because the ultimate number of children sharing in the gift will be known within twenty-one years after the death of a person alive at $A$ 's death, namely $B$. Under "wait and see" coupled with cy pres, no reformation is required. ${ }^{109}$

(2) $B$ dies survived by children, one or more of whom are under four years of age, but all of whom were alive at $A$ 's death. The gift to children of $B$ is good under "wait and see" because the ultimate number of children sharing in the gift will be known within lives in being at $A$ 's death, namely the children of $B$. Under "wait and see" coupled with cy pres, no reformation is required. 110

(3) $B$ dies survived by four children, two of whom ( $C$ and $D$ ) are under four years of age and were unborn at $A$ 's death and two of whom ( $E$ and $F$ ) were alive at $A$ 's death. No child of $B$ alive at $A$ 's death or born thereafter has attained twenty-five at $B$ 's death. Determination of the validity of the gift to children is deferred. Five years after $B$ 's death $(C, D$, and $E$ being still alive), $F$ attains twentyfive and is entitled to distribution of a minimal share. $C, D$, and $E$ will attain twenty-five, or not, within $F$ 's lifetime and twenty-one years. The gift to children of $B$ is good under "wait and see" be-

\footnotetext{
${ }^{108}$ Freund, Three Suggestions Concerning Future Interests, 33 HARv. L. REv. 526, 533 (1920).

100 DUKeMTINER 85.

${ }^{110}$ BrégX 5270; Dukemtnier 85.
} 
cause the ultimate number of children sharing in the gift will be fixed within the perpetuities period.111 Under "wait and see" coupled with cy pres, no reformation is required.

(4) $B$ dies survived by four children, two of whom ( $C$ and $D$ ) are under four years of age (being one and two, respectively) and were unborn at $A$ 's death and two of whom ( $E$ and $F$ ) were alive at $A$ 's death. No child of $B$ alive at $A$ 's death or born thereafter has attained twenty-five at $B$ 's death. Determination of the validity of the gift to children is deferred. ${ }^{112}$ One year after $B$ 's death $(C$ and $D$ being still alive), $E$ and $F$ die without attaining twenty-five. $G$ and $D$ cannot attain twenty-five within the perpetuities period, and the gift to children of $B$ is bad under "wait and see." Under "wait and see" coupled with cy pres, the gift to children is reformed to read "remainder to such of the children of $B$ as attain twenty-one." Reformation assures validity under the Rule Against Perpetuities, but it does not assure vesting. If a child of $B$ alive at $A$ 's death or born thereafter (including $E$ and $F$ ) had attained twentyone, the successors of such child should share in the gift as reformed. If no child of $B$ alive at $A$ 's death or born thereafter attains twenty-one, the gift to children of $B$ fails by virtue of its own limitation.

(5) The only children born to $B$ are $C, D$, and $E$, all of whom were unborn at $A$ 's death, all of whom survive $B$, and all of whom are under four years of age at $B$ 's death. The gift to the children of $B$ is bad under "wait and see" because the children of $B$ cannot attain twenty-five within twenty-one years after the death of a person alive at $A$ 's death, namely $B .{ }^{113}$ Under "wait and see" coupled with cy pres, the gift to children is reformed at $B$ 's death to read "remainder to such of the children of $B$ as attain twenty-one."114 Reformation assures validity under the Rule Against Perpetuities, but it does not assure vesting. If $C, D$, and $E$ all die without attain-

\footnotetext{
${ }^{111}$ BRÉgY 5270. Dukeminier says that "if ... at ... [ $B$ 's] death there is a child of ... [B] under four who was born after ... [A's] death, the will is reformed to give the property to such of ... [B's] children as reach twenty-one. The justification is that testator obviously would prefer earlier vesting to total invalidity. . ..." (Emphasis supplied.) DUReminEr 85. Total invalidity is not inevitable in the case put. Although reformation might occur at $B$ 's death under some circumstances (see example (5) in the group above), it may properly be deferred to a time beyond $B$ 's death. See note 85 supra.

112 BRÉGY 5270.

113 Ibid.

214 DUREMINIER 85.
} 
ing twenty-one, the gift to children of $B$ fails by virtue of its own limitation.

\section{VII}

\section{Powers of Appointment}

\section{A. Powers Under the Rule in Orthodox Form}

For perpetuities purposes, a general power to appoint by deed or will is comparable to ownership of the property subject to the power because the donee of the power can appoint to himself or his estate. A general power to appoint by deed or will which is acquired contemporaneously with its creation is the perpetuities equivalent of an indefeasibly vested remainder and is exempt from the Rule Against Perpetuities. If $A$ bequeaths $\$ 100,000$ "to $T$ and his heirs, in trust, to pay the net income to $B$ for life, then to pay the net income to the children of $B$ for their lives, and then to pay the principal to $C$ and his heirs," the remainder in $C$ is indefeasibly vested and exempt from the Rule. If $A$ bequeaths $\$ 100,000$ "to $T$ and his heirs, in trust, to pay the net income to $B$ for life, then to pay the net income to the children of $B$ for their lives, and then to pay the principal to such person or persons as $C$ by deed or will appoints," the general power in $C$ to appoint by deed or will is comparable to an indefeasibly vested remainder and is exempt from the Rule. ${ }^{115}$

If acquiring a general power to appoint by deed or will is deferred beyond the time the instrument creating the power takes effect, the power is good under the Rule if it must be acquired, if acquired at all, within the perpetuities period. Under such circumstances, acquiring the power is treated like the vesting of a contingent interest in the property subject to the power. If $A$ bequeaths $\$ 100,000$ "to $T$ and his heirs, in trust, to pay the net income to $B$ for life, and then to pay the principal to the first-born son of $B$," and $B$ is a bachelor at $A$ 's death, the contingent remainder is good under the Rule because it is certain to vest, if it vests at all, within the perpetuities period. If $A$ bequeaths $\$ 100,000$ "to $T$ and his heirs, in trust, to pay the net income to $B$ for life, and then to pay the principal to such person or persons as the first-born son of $B$ by deed or will appoints," and $B$ is a bachelor at $A$ 's death, the gen-

\footnotetext{
${ }^{115} 3$ SIMIES \& SMITH $\S 1272$. Powers of sale in trustees and mortgagees are administrative rather than dispositive in character and thus are exempt from the Rule. 6 A.L.P. § 24.63.
} 
eral power is good under the Rule because acquisition of the power is certain to occur, if it occurs at all, within the perpetuities period.110

For perpetuities purposes, a general testamentary power of appointment is the equivalent of a special power. A general testamentary or a special power is bad under the Rule if it might be exercised beyond the perpetuities period, because the test for validity under the Rule is a possibilities ${ }^{117}$ test. A possible appointment of an interest by the exercise of a general testamentary or a special power at a remote time is comparable to the possible vesting at a remote time of a contingent remainder or a contingent executory interest. If $A$ bequeaths $\$ 100,000$ "to $T$ and his heirs, in trust, to pay the net income to $B$ for life, then to pay the net income to the children of $B$ for their lives, and then to pay the principal to such of the grandchildren of $B$ as the eldest child of $B$ shall by deed or will appoint," and $B$ is a bachelor at $A$ 's death, the special power is bad under the Rule because it might be exercised at a remote time.

The possible acquisition at a remote time of a general power to appoint by deed or will and the possible exercise at a remote time of a general testamentary or special power affect the validity of the powers themselves under the Rule in the same way that the possible vesting at a remote time affects the validity of a contingent executory interest or a contingent remainder: such powers are void ab initio.

The validity of an appointment made by the exercise of a general power to appoint by deed or will is determined by computing the perpetuities period from the time the power is exercised because a general power to appoint by deed or will is comparable to ownership of the property subject to the power. If $A$ bequeaths $\$ 100,000$ "to $T$ and his heirs, in trust, to pay the net income to $B$ for life, then to pay the net income to the children of $B$ for their lives, and then to pay the principal to such person or persons as $C$ by deed or will appoints," and $C$ appoints the principal by will "to $D$ for life, remainder to such of the children of $D$ as survive $D$," the appointment is good under the Rule because the children of $D$ who survive $D$, including children of $D$ born after the exercise of $C$ 's power, will be known at the death of $D$, a person alive at the exercise of the power. ${ }^{118}$

\footnotetext{
${ }^{216} 6$ A.L.P. § 24.31; 3 SIMES \& SMrTH § 1272.

${ }^{217} 6$ A.L.P. \& 24.32; 3 SIMIES \& SMITH $\$ 1273$.

${ }^{118} 6$ A.L.P. $\$ 24.33 ; 3$ SIMES \& SMITH $\$ 1274$.
} 
The validity of an appointment made by the exercise of a general testamentary or special power is determined by "reading back" or interpolating the appointment into the instrument creating the power and computing the perpetuities period from the time the power was created. If $A$ bequeaths $\$ 100,000$ "to $T$ and his heirs, in trust, to pay the net income to $B$ for life, and then to pay the principal to such of the children of $B$ as $B$ shall by deed or will appoint, and in default of appointment, to pay the principal to $C$ and his heirs," and $B$ by will appoints the entire principal "to such of my $[B$ 's] children as survive me, share and share alike," the appointment is good under the Rule because when it is read back into $A$ 's will, it is the equivalent of "to pay the net income to $B$ for life, and then to pay the principal to such of the children of $B$ as survive $B$, share and share alike." The children of $B$ who survive $B$, including children of $B$ born after the creation of the power, will be known at the death of $B$, a person alive at the creation of the power. ${ }^{119}$

Although the validity of an appointment made by the exercise of a general testamentary or special power is determined by computing the perpetuities period from the time the power was created, facts existing at the time of the appointment are considered. If $A$ bequeaths $\$ 100,000$ "to $T$ and his heirs, in trust, to pay the net income to $B$ for life, and then to pay the principal to such of the children of $B$ as $B$ shall by deed or will appoint, and in default of appointment, to pay the principal to $C$ and his heirs," and $B$ by will appoints the entire principal "to such of my $[B$ 's $]$ children as attain twenty-five," the appointment is good under the Rule if the youngest of $B$ 's children is at least four years old at $B$ 's death. Read back into $A$ 's will, the appointment is the equivalent ${ }^{120}$ of "to pay the net income to $B$ for life, and then to pay the principal to such of the children of $B$ as survive $B$ and attain twenty-five not later than twenty-one years after $B$ 's death." The children of $B$ who attain twenty-five, including the youngest of $B$ 's children, born after the creation of the power, will be known at the latest within twenty-one

\footnotetext{
${ }^{110} 6$ A.L.P. $\$ 24.34 ; 3$ SIMES \& SMITH $\S 1274$.

120 The equivalence is for perpetuities purposes only. Had a child of $B$ attained twenty-five after $A$ 's death and predeceased $B$, such a child would qualify to share in the remainder (perpetuities questions apart) had $A$ himself created the remainder. However, such a child would not qualify to share in the "remainder" created by $B$ 's exercise of the power of appointment. 5 A.L.P. $\$ 23.46$.
} 
years after the death of $B$, a person alive at the creation of the power. ${ }^{121}$

B. Powers of Appointment Under "Wait and See" and Under "Wait and See" Coupled with Cy Pres

Under the Rule in orthodox form, an appointment made by the exercise of a general testamentary or special power is read back into the instrument creating the power, and the perpetuities period is measured from the date the power was created. However, facts existing at the time of the appointment are considered in determining the validity of the appointment. The "second look" aspect of the orthodox Rule was used to buttress the case for "wait and see," but "wait and see" as applied to powers and appointments goes much further than the "second look" aspect of the orthodox Rule.122 Both the validity of the power and the validity of appointments are determined by actualities, not possibilities. If $A$ bequeaths $\$ 100,000$ "to $T$ and his heirs, in trust, to pay the net income to $B$ for life, and then to pay the principal to such person or persons as that son of $B$ who first attains twenty-five by deed or will appoints," and $B$ is a bachelor at $A$ 's death, the validity of the general power cannot be demonstrated at $A$ 's death, and determination of validity is deferred.

(1) If a son of $B$ attains twenty-five during $B$ 's lifetime or within twenty-one years after $B$ 's death, the power is good under "wait and see," and under "wait and see" coupled with cy pres, no reformation is required.

(2) If no son of $B$ attains twenty-five during $B$ 's lifetime, and all sons of $B$ are under four years of age at $B$ 's death, the power is bad under "wait and see" because it cannot be acquired within the perpetuities period. Under "wait and see" coupled with cy pres, the power is reformed to read "and then to pay the principal to such person or persons as that son of $B$ who first attains twenty-one by deed or will appoints."

(3) If no son of $B$ attains twenty-five during $B$ 's lifetime, and $B$ is survived by sons, one or more of whom are over four years of age, and one or more of whom are under four years of age, a son of $B$ might attain twenty-five during the perpetuities period, namely $B$ 's lifetime and twenty-one years. Under "wait and see" coupled

1216 A.L.P. \$ 24.35; 3 SIMIES \& SMITH § 1274.

122 BREGY 5282. 
with cy pres, should the power be reformed at $B$ 's death to read "and then to pay the principal to such person or persons as that son of $B$ who first attains twenty-one by deed or will appoints"? Reformation at $B$ 's death increases the likelihood that a son of $B$ will qualify for the power, but it does so at the cost of failing to approximate most closely the intention of the creator of the interest. Reformation should be resorted to only when all sons of $B$ over four years of age at $B$ 's death have died without attaining twenty-five, survived by $a$ son or sons of $B$ under four years of age at $B$ 's death. Then, and not before, is it clear that actual rather than possible events preclude vesting, if at all, within the perpetuities period.

$A$ bequeaths $\$ 100,000$ "to the $T$ Trust Company, in trust, to pay the net income to $B$ for life, and then to pay the net income to such of the children of $B$, to one or more to the exclusion of other or others, and in such shares and proportions, and at such time or times, as the trustee shall select, and at the death of the survivor of $B$ 's children, to pay the principal to $C$ and his heirs." "Children" is construed to mean "children of $B$ whenever born." $B$ is capable of conceiving a child at and after $A$ 's death. The validity of the discretionary power in its entirety cannot be demonstrated at $A$ 's death, and the determination of validity is deferred.123

(1) No child is born to $B$ after $A$ 's death. Validity of the discretionary power in its entirety under "wait and see" can be demonstrated at $B$ 's death or at the time that $B$ for any reason becomes incapable of conceiving a child. An effective appointment made in the exercise of the power must be made, if at all, to a child or children of $B$ alive at $A$ 's death. Under "wait and see" coupled with cy pres, no reformation is required.

(2) $B$ dies survived by a child or children, one or more of whom were born after $A$ 's death. Validity of the discretionary power in its entirety cannot be demonstrated at $B$ 's death because the trustee might make an appointment of income to a child of $B$ beyond twenty-one years after the death of $B$ and $B$ 's children alive at $A$ 's death. All afterborn children of $B$ predecease a child or children of $B$ alive at $A$ 's death. The power is good in its entirety under "wait and see" because any effective appointment must be made, if at all, within the life or lives of a child or children of $B$ alive at $A$ 's death.

\footnotetext{
123 BRÉGY 5282. A declaration of the validity of the discretionary power for the perpetuities period is of course permissible both at and after $A$ 's death.
} 
Under "wait and see" coupled with cy pres, no reformation is required.

(3) $B$ dies survived by a child or children, one or more of whom were born after $A$ 's death. The validity of the discretionary power in its entirety cannot be demonstrated at $B$ 's death because the trustee might make an appointment of income to a child of $B$ beyond twenty-one years after the death of $B$ and $B$ 's children alive at $A$ 's death. All of $B$ 's children alive at $A$ 's death die, survived by an afterborn child of $B$.

(a) If the afterborn child of $B$ dies within twenty-one years after the death of the survivor of $B$ 's children alive at $A$ 's death, the power is good in its entirety under "wait and see" because any effective appointment must be made, if at all, within the perpetuities period, namely the lives of $B$ and $B$ 's children alive at $A$ 's death and twenty-one years. ${ }^{124}$ Under "wait and see" coupled with cy pres, no reformation is required.

(b) If the afterborn child of $B$, the remainderman $C$, the successors of $A$, and the trustee all agree to terminate the trust ${ }^{125}$ twenty-one years after the death of the survivor of $B$ 's children alive at $A$ 's death, the power is good in its entirety under "wait and see,"128 and under "wait and see" coupled with cy pres, no reformation is required.

(c) If the afterborn child of $B$ lives beyond the perpetuities period, the discretionary power is bad beyond the perpetuities period under "wait and see." Otherwise effective appointments of income to children of $B$ made during the perpetuities period are good.127 Under "wait and see" coupled with cy pres, the power may be reformed to read "and then to pay the net income to such of the children of $B$, to one or more to the exclusion of other or others, and in such shares and proportions, and at such time or times, as the trustee shall select within a period measured by the lives of $B$ and $B$ 's children alive at my [ $A$ 's] death and twenty-one years." 128

${ }^{124}$ Ibid.

1253 Scort, TRUSTS $\S 337$ (2d ed. 1956).

${ }^{128}$ BRÉGY 5282.

127 DUKEMINIER 90.

${ }^{128}$ Dukeminier says that at the end of the perpetuities period the discretionary power "lapses." Ibid. 
$A$ bequeaths $\$ 100,000$ "to $T$ and his heirs, in trust, to pay the net income to $B$ for life, and then to pay the principal to such of the children of $B$ as $B$ shall by deed or will appoint, and in default of appointment, to pay the principal to $C$ and his heirs." $B$ dies survived by four children, two of whom $(C$ and $D$ ) are under four years of age (being one and two, respectively) and were unborn at $A$ 's death, and two of whom ( $E$ and $F$ ) were alive at $A$ 's death. No child of $B$ has attained twenty-five at $B$ 's death. $B$ by will appoints the entire principal "to such of my [ $B$ 's] children as attain twenty-five." Read back into $A$ 's will, the appointment is the equivalent ${ }^{129}$ of "to pay the net income to $B$ for life, and then to pay the principal to such of the children of $B$ as survive $B$ and attain twenty-five." The validity of the appointment cannot be demonstrated at $B$ 's death, and determination of validity is deferred. One year after $B$ 's death ( $C$ and $D$ being still alive), $E$ and $F$ die without attaining twenty-five. $C$ and $D$ cannot attain twenty-five within the perpetuities period, namely the lives of $B$ and $B$ 's children alive at $A$ 's death and twenty-one years; and the appointment to children of $B$ is bad under "wait and see." Under "wait and see" coupled with cy pres, the appointment to children is reformed to read "remainder to such of my [ $B$ 's] children as attain twenty-one." Had $E$ or $F$ attained twenty-one before dying, the successors of such child should share in the appointment as reformed.

\section{VIII}

FUnGTIONAL EQUIVALENTS, INFEGTIOUS INVALIDITY, AND SEPARABILITY A. Functional Equivalents

It is conventional to differentiate among contingent remainders, contingent executory interests, resulting trusts, possibilities of reverter, and rights of entry for condition broken for perpetuities purposes. Contingent remainders and contingent executory interests are subject to the Rule, while resulting trusts, possibilities of reverter, and rights of entry for condition broken are exempt from the Rule. A contingent executory interest, it is said, must be so created that it becomes possessory, if it takes effect at all, within the perpetuities period. ${ }^{130}$ A contingent remainder must be so created

\footnotetext{
120 See note 120 supra.

${ }^{130}$ The conventional statement is as follows: "An executory interest (that is, an interest which cuts off a previous estate rather than follows after it when it has terminated) is not 'vested' until the time comes for taking possession." 6 A.L.P. $\$ 24.3$.
} 
that it at least vests in interest, if it vests at all, within the perpetuities period. In some contexts these differentiations are breaking down:

(1) $A$ devises "to $B$ and his heirs so long as the land is used for church purposes, then to $C$ and his heirs." $B$ has a fee simple determinable, exempt from the Rule. $C$ has a contingent executory interest, bad under the Rule because it might vest, if at all, beyond the perpetuities period. The void limitation is stricken from the will, and $B$ has a fee simple determinable. The estate of $A$, by implication, has a possibility of reverter. However, there is authority for the validity of the contingent executory interest under the Rule, even though it might vest remotely. ${ }^{131}$

Leach's earlier statement is substantially the same: "executory interests do not have the capacity of vesting in interest before they vest in possession. Thus the Rule . . . requires that executory interests become possessory within lives aud 21 years." Leach, Perpetuities in a Nutshell, 51 HARv. L. REv. 638, 648 (1938). The difficulty in working with Leach's statement originates in the use of the words "possession" and "possessory." Gray's statement with respect to the vesting of executory interests is likely to cause less difficulty than that of Leach: "Springing and shifting uses and . . . executory devises are not vested interests until they take effect in possession or are turned into vested remainders." GRAY 108. (Emphasis added.) Recent cases support a statement like that of Gray: A contingent executory interest must be so created that it will become possessory, or vested in interest, or be transformed into a vested remaiuder or a vested estate, if at all, not later than twenty-one years after some life in being at the creation of the interest. Ianier v. Lanier, $218 \mathrm{Ga} .137,126$ S.E.2d 776 (1962); Forbringer v. Romano, 7 N.J. Super. 432, 71 A.2d 660 (Ch.), aff'd, 10 N.J. Super. 175, 76 A.2d 825 (App. Div. 1950); Howard's Estate, 54 Pa. D. \& C. 312 (1943); Harris v. France, 33 Tenn. App. 333, 232 S.W.2d 64 (1950). Once the contingent executory interest has vested, Scott treats the problem of postponement of eujoyment as one of trust termination. 1 ScoTr, TRUsTs $\$ 62.10$ (2d ed. 1956).

${ }^{131}$ In Brown v. Terra Bella Irrigation Dist., 51 Cal.2d 33, 330 P.2d 775 (1958), land was granted to the district with a "reservation" of all gas, oil, and minerals underlying the land. The reservation was to continue for twenty-five years from delivery of the deed and as loug thereafter as profitable. Subject to the reservation, the deed granted all of the land "together with ... the reversion and ... remainder" to the district. The Supreme Court of California held that even if the gift over to the district following the reserved fee simple determinable were void under the Rule, an "interest in reversion" passed to the district under the deed.

Brown v. Terra Bella Irrigation Dist. involved an inter vivos transfer. Its counterpart in the testamentary field is Brown v. Independent Baptist Ghurch, 325 Mass. 645,91 N.E.2d 922 (1950). There the testatrix in 1849 devised land to a church "so long as they shall maintain and promulgate their present religious belief and faith and shall continue a Church," then to ten named persons who were also the residuary devisees. In 1939 the church ceased to exist. In a suit to detcrmine whether the property passed to the successors in interest of the heirs at law of the testatrix or to the successors in interest of the residuary devisees, the Supreme Judicial Court of Massachusetts held that the gift over was void under the Rulc Against Perpetuities. The possibility of reverter passed to the ten named persons under the residuary clause.

In neither the Irrigation District case nor the Baptist Church case is the equivalence of the executory interest and the possibility of reverter following a determinable fec conceded. Although nothing is made of the fact that it is illogical under orthodox 
(2) $A$ bequeaths $\$ 100,000$ to trustees "for the sole benefit of the first-born son of $B$, payable on his attaining twenty-five." $B$ is a bachelor at $A$ 's death. The contingent executory interest is good under the Rule because any son born to $B$ must be born, if at all, within $B$ 's lifetime and the normal period of gestation. Upon a son being born to $B$, the contingent executory interest is transformed into an indefeasibly vested equitable estate; but possession or enjoyment may properly be withheld from the first-born son of $B$ until he reaches twenty-five, a time which might be remote under the Rule. 132

\section{B. Infectious Invalidity}

A limitation which is bad under the Rule Against Perpetuities is ordinarily stricken from the dispositive instrument, and other limitations are permitted to take effect as if the void limitation had not been written. ${ }^{133}$ However, if the bad limitation is found to be essential to the donor's dispositive scheme, the bad limitation takes with it limitations in themselves good under the Rule. This is the doctrine of infectious invalidity. ${ }^{134}$ There is no satisfactory formula for predicting use of the doctrine by a court deciding a perpetuities case. ${ }^{135}$

Most of the bad limitations are ultimate or end limitations because draftsmen working at the outer limits of the perpetuities period are more likely to violate the Rule. Most modern authorities, however, hold that it is no more difficult to separate a prior limitation which is bad from a subsequent or ultimate limitation which is in

doctrine to invalidate an executory interest which might vest remotely and at the same time permit the transfer to a stranger of a possibility of reverter having the same characteristic of remoteness in fact, if not in law, it is difficult to believe that the judges in both cases were unaware of what they were doing. Both decisions are explainable on technical grounds, but the technical explanations are unsatisfactory. As Simes dryly observed when discussing the Baptist Church case: "The testatrix ... did not die twice. . ." Simes, Is the Rule Against Perpetuities Doomed?, 52 Mich. L. REv. 179, n.4 (1953).

Under $\$ 715.8$ of the California Civil Code enacted in 1963, the executory interest in $C$ in the hypothetical case posed in the text is vested. That statute reads in part as follows: "An interest in real or personal property, legal or equitable, is vested if and when there is a person in being who could convey or there are persons in being, irrespective of the nature of their respective interests, who together could convey a fee simple title tbereto." CAL. Crv. Code ANN. \$ 715.8 (Supp. 1963). See note 13 supra. ${ }^{132}$ GraY 119-21. In Hunt v. Carroll, 157 S.W.2d 429 (Tex. Civ. App. 1941), the court denied that an executory interest must be so created that it becomes possessory, if it takes effect at all, within the perpetuities period.

${ }^{133} 6$ A.L.P. $\$ 24.47$.

13є Id. $\$ 24.48$.

${ }^{135}$ Ibid. 
itself good, than it is to separate an ultimate limitation which is bad from a prior limitation or limitations which are in themselves good. ${ }^{136}$

Brégy says that under Pennsylvania's "wait and see" statute "separation of the good interests from the bad [is required] in all cases and the question of separability will become moot." 137 However, if a contingent remainder or a contingent executory interest is necessarily bad $a b$ initio even under "wait and see," so that a declaration of invalidity is permissible at the creation of the interest, the doctrine of infectious invalidity is not dead, but moribund.138 Under cy pres alone, the doctrine is dead to the extent that reformation precludes any violation of the Rule. Under "wait and see" coupled with cy pres, it is dead both to the extent that reformation precludes any violation of the Rule and to the extent that interests of limited duration have run before a declaration of invalidity is sought. ${ }^{130}$

\section{G. Separability}

Explicit expression of implicit alternative contingencies is critical. $A$ bequeaths $\$ 10,000$ "to that son of $B$ who first becomes a clergyman, but if $B$ dies without having a son, or if no son of $B$ becomes a clergyman, then to $C$." No son of $B$ is a clergyman at $A$ 's death, and "son of $B$ " is construed to mean "son of $B$ whenever born." The contingent executory interest in $C$ which is expressly conditioned on $B$ 's dying without having a son is good under the Rule because the contingency must be resolved at a time not later than $B$ 's death, and $B$ is a life in being at $A$ 's death. The contingent executory interest which is expressly conditioned on no son of $B$ becoming a clergyman is bad under Rule because the contingency might be resolved beyond the perpetuities period, namely $B$ 's lifetime and twenty-one years. If $B$ dies without having a son, the executory interest in $C$ becomes possessory. If $B$ has a son or sons, none of whom becomes a clergyman, the executory interest in $C$ is bad under the Rule even though no son of $B$ has become a clergyman at $B$ 's death and $B$ 's sons surviving him all die within twentyone years after $B$ 's death, none having become a clergyman. ${ }^{140}$

\footnotetext{
${ }^{136}$ Id. $\$ 24.51$.

${ }^{137}$ BRÉGY 5268.

${ }^{138}$ See note 64 supra.

${ }^{139}$ DUREMINIER 49.

${ }^{140} 6$ A.L.P. $\$ 24.54$.
} 
Failure to express alternative contingencies implicit in a gift causes invalidity under the Rule. $A$ bequeaths $\$ 10,000$ "to that son of $B$ who first becomes a clergyman, but if no son of $B$ becomes a clergyman, then to $C$." No son of $B$ is a clergyman at $A$ 's death, and "son of $B$ " is construed to mean "son of $B$ whenever born." The contingent executory interest in $C$ is implicitly conditioned on at least two contingencies: (1) $B$ 's dying without having a son, a contingency which must be resolved at a time not later than $B$ 's death, and $B$ is a life in being at $A$ 's death; and (2) $B$ 's having one or more sons, none of whom becomes a clergyman, a contingency which might be resolved beyond the perpetuities period. The executory interest in $C$ is bad under the Rule even though $B$ dies without having a son at all. 141

The form of expression used by the draftsman has important consequences in related but different contexts. $A$ devises "to $B$ for life, remainder to the first-born son of $B$, but if such son dies under twenty-five, to such of his children as survive him." $B$ is a bachelor at $A$ 's death. The contingent remainder to the first-born son of $B$ is in itself good under the Rule, because any son born to $B$ must be born, if at all, within $B$ 's lifetime and the normal period of gestation. The contingent remainder to the children of such son is bad under the Rule, because the contingency might be resolved beyond the perpetuities period, namely $B$ 's lifetime and twenty-one years. The contingent remainder to the children of the first-born son, called a condition subsequent, is stricken from the will, and the devise reads "to $B$ for life, remainder to the first-born son of $B$." Had the testator devised "to $B$ for life, remainder to the first-born son of $B$ if he attains twenty-five," and $B$ was a bachelor at $A$ 's death, the contingent remainder would fail under the Rule. ${ }^{142}$

\section{IX}

\section{Gifts to Gharities}

With one exception, the common law Rule Against Perpetuities invalidates contingent future gifts to charities which might vest be-

\footnotetext{
${ }^{2+1}$ Ibid. Under "wait and see" and under "wait and see" coupled with cy pres, the contingent executory interest takes effect if the contingency is resolved favorably with respect to $C$ not later than twenty-one years after the death of $B$ and $B$ 's sons alive at $A$ 's death. A favorable resolution of the contingency with respect to $C$ is $B$ 's dying without having a son at all.

${ }^{242} 6$ A.L.P. $\$ 24.47$. For disposition of this kind of case under "wait and see," consult BRÉGY 5279.
} 
yond the perpetuities period, if they vest at all. That exception is this: a gift over from one charity to another charity upon a contingency which might be resolved remotely, if resolved at all, is good. ${ }^{143}$ Although it is occasionally asserted that courts require less to constitute a vesting when a gift is made to a charity, ${ }^{144}$ evidence to support the assertion has not been systematically assembled.

\section{$\mathrm{X}$}

Some Suggestions with Respect to

DRAFTSMANSHIP aND LITIGation

Generally speaking, applying the orthodox, the "wait and see," or the cy pres version of the Rule Against Perpetuities presupposes analyzing the limitations as of the time of their creation to determine (1) whether any gifts are future (as opposed to present or immediate), (2) whether any future gifts are remainders or executory interests (as opposed to reversions, possibilities of reverter, resulting trusts, or rights of entry for condition broken), and (3) whether any remainders or executory interests are contingent (as opposed to vested).

If a contingent future interest might vest, if it vests at all, at a remote time, it is bad ab initio under the Rule in orthodox form. Under cy pres, reformation may be appropriate. Under "wait and see" a contingent future interest which might vest remotely, if it vests at all, is not necessarily bad $a b$ initio. If the contingency might be resolved within the perpetuities period as measured by actual rather than possible events, the determination of validity is deferred, and under some circumstances determination of validity may properly be deferred to a time beyond the running of the perpetuities period..$^{145}$ "Wait and see" sets the limits within which a contingent future interest must vest, if at all, or fail under the Rule: that is, "wait and see" tells us when a contingent future interest is deemed bad, not when the determination of invalidity is made. Cy pres tells us that a contingent future interest may be reformed, not when reformation occurs. Generally speaking, "wait and see" does not dictate the time for determining validity. ${ }^{146}$ If "wait and see" is coupled with cy pres, the cy pres feature of the Rule does not, gen-

\footnotetext{
${ }^{143} 6$ A.L.P. § 24.40; 3 SIMES \& SMITTH § 1280.

144 Note, 27 Rocky MT. L. Rev. 103, 104 n.13 (1954).

${ }^{115}$ Case $3(\mathrm{~b})$ in the text at page 230 supra.

${ }^{148}$ But see note 85 supra.
} 
erally speaking, dictate the time of reformation. Individualization of the case before the court is the essence of cy pres and "wait and see" coupled with cy pres.

"Wait and see" (and a fortiori "wait and see" coupled with cy pres) is less strict than the Rule in orthodox form because (1) it invalidates a contingent future interest only on the basis of actual events, rather than possibilities, (2) it ordinarily does not invalidate a contingent future interest $a b$ initio, and (3) it allows a somewhat greater freedom of choice with respect to measuring lives. Even so, "wait and see," cy pres, and "wait and see" coupled with cy pres are palliatives, not cure-alls. The prudent draftsman appreciates their existence, but he drafts to comply with the requirements of the Rule in orthodox form even in a jurisdiction which has accepted them. ${ }^{14 \tau}$ He does this because the Rule in orthodox form gives the skilled draftsman as much freedom as he needs. Specifically, he should:

(1) Avoid using future interests altogether unless the drafting problem at hand clearly calls for them. Draftsmen do both their clients and themselves a disservice in silently acquiescing in the indiscriminate creation of future interests. Many trust termination cases testify to the proclivity of testators to overestimate the extent of their wealth. An outright devise or bequest, unencumbered by future interests, powers, or trusts, is frequently the most sensible kind of gift.

(2) Avoid using words of vague reference. A bequest to trustees "to pay the income to $B$ for life, then to $B$ 's children for their lives, and then to pay the principal to $B$ 's grandchildren then surviving" is replete with uncertainties. "Pay the principal" when? At the death of a child of $B$ although such deceased child is survived by one or more other children of $B$ ? At the death of the survivor of $B$ 's children? "Pay the principal" how? So that the share of each grandchild of $B$ is equal to that of any other grandchild, be he sibling or cousin? "Grandchildren ... surviving" whom? Their parents? The survivor of $B$ 's children? It will not do to say that questions of this sort can be answered by construction. Of course they can, but all too often only at the price of a lawsuit.

(3) Avoid class desiguations of a highly generalized sort if possible. If $B$ is incapable of conceiving a child at and after the

${ }^{147}$ BREgY 5256; DUkEMINIER 91; Mechem, Further Thoughts on the Pennsylvania Perpetuities Legislation, 107 U. PA. L. REv. 965, 983 (1959). 
execution of the will, a devise "to $B$ for life, then to $B$ 's widow for life, remainder to such of $B$ 's four children, namely James, John, Mary, and Alice, as survive the survivor of $B$ and $B$ 's widow" is preferable to a devise "to $B$ for life, then to $B$ 's widow for life, remainder to such of $B$ 's children as survive the survivor of $B$ and $B$ 's widow." The contingent remainder to the children of $B$ in the former case is clearly good under the Rule. The validity of the contingent remainder to the children of $B$ in the latter case turns on construction.

(4) Avoid conditioning gifts on attaining an age beyond twentyone. Although inroads have been made on the "all-or-nothing" rule of Leake $v$. Robinson, ${ }^{148}$ it remains a continuing threat in many jurisdictions.

(5) Avoid creating trusts which may last beyond the perpetuities period. The law on the duration of trusts is still developing. ${ }^{140}$

(6) Use Leach and Logan's perpetuities saving clause ${ }^{150}$ if the complexity of the dispositive instrument justifies including it. A saving clause is not a substitute for good drafting; rather, it complements good drafting. Even a skilled lawyer working at the outer limits of the perpetuities period may unwittingly violate a facet of the Rule only vaguely recognized and not yet clearly articulated. His instrument ought not to be jeopardized by a policy decision on a question which was open at the time of execution.

When the instrument of transfer has taken effect and the perpetuities question is no longer theoretical, the lawyer already versed in the mechanics of the Rule should (when appropriate):

(1) Check for the existence of statutes which complement the Rule by conditioning the continued existence of a possibility of reverter or a right of entry for condition broken on the timely registration of a "preserving notice."151

\footnotetext{
148 2 Mer. 363, 35 Eng. Rep. 979 (Ch. 1817).

${ }^{1 * 9}$ Newman, Perpetuities, Restraints on Alienability, and the Duration of Trusts, 16 VAND. L. REv. 57 (1962).

${ }^{260}$ Leach \& Logan, Perpetuities: A Standard Saving Clause to Avoid Violations of the Rule, 74 HARv. L. REv. 1141 (1961).

${ }^{161}$ E.g., such record marketable title shall be subject to: "All interests and defects which are inherent in the muniments of which such chain of record title is formed; ... provided that possibilities of reverter, and rights of entry or powers of termination for breach of condition subsequent, which interests are inherent in the muniments of which such chain of record title is formed and which have existed for forty years or more, shall be preserved and kept effective only in the manner [hereinafter] provided....

"Any person claiming an interest in land may preserve and keep effective such
} 
(2) Check for the existence of statutes which both complement and supersede the Rule by conditioning the continued existence of a possibility of reverter, an executory interest after a fee simple determinable, or a right of entry for condition broken on a fee simple on the occurrence of the contingency within a specified period, such as thirty years. ${ }^{152}$

(3) Stress the freedom made available to a court by the rules of construction and press for a construction consistent with the claim advanced.153

(4) Urge assimilation of future interests of like function (contingent remainders, contingent executory interests, possibilities of reverter, rights of entry for condition broken, and resulting trusts) where the result turns solely on the label attached to the interest.154

(5) Stress decisions rejecting differences based on irrelevant choice of method where the grantor, settlor, or testator has failed to use conventional techniques. ${ }^{155}$

interest by filing for record during the forty-year period immediately following the effective date of the root of title of the person whose record title would otherwise be marketable, a notice in writing... setting forth the nature of the claim...." OHIO Rev. Code ANN. $\S \S 5301.49$, .51 (Page Supp. 1963); Smith, The New Marketable Title Act, 22 Oнго ST. L.J. 712, 718 (1961).

${ }^{152}$ E.g., "A fee simple determinable in land or a fee simple in land subject to a right of entry for condition broken shall become a fee simple absolute if the specified contingency does not occur within thirty years from the date when such fee simple determinable or such fee simple subject to a right of entry becomes possessory. If such contingency occurs within said thirty years the succeeding interest, which may be an interest in a person other than the person creating the interest or his heirs, shall become possessory or the right of entry exercisable notwithstanding the rule against perpetuities." Mass. ANN. LAws ch. 184A, \$ 3 (Supp. 1962); Leach, Perpetuities Legislation, Massachusetts Style, 67 HARv. L. REv. 1349, 1362 (1954).

${ }_{163}$ Statutes stating a preferred rule of construction applicable in particular instances exist in some states. E.g., "The vesting of any limitation of property, whether created in the exercise of a power of appointment or in any other manner, shall not be regarded as deferred for purposes of the rule against perpetuities merely because the limitation is made to the estate of a person or to a personal representative, or to a trustee under a will, or to take effect on the probate of a will...." ILL. ANN. STAT. ch. 30, § 153 (a) (Smith-Hurd Supp. 1963).

${ }^{154}$ Lynn \& Ramser, Applying the Rule Against Perpetuities to Functional Equivalents: Copps Chapel and the Woburn Church Revisited, 43 IowA L. REv. 36 (1957); Lynn \&. Van Doren, Applying the Rule Against Perpetuities to Remainders and Executory Interests: Orthodox Doctrine and Modern Cases, 27 U. CHI. L. REv. 436 (1960).

${ }^{156}$ Lynn, Reforming the Common Law Rule Against Perpetuities, 28 U. CHI. L. REv. 488, 492. (1961). 


\section{XI}

\section{Conclusion}

Gray made the common law Rule Against Perpetuities a rule against remoteness of vesting and urged remorseless appplication of the Rule. Through a chance combination of factors-persistent insistence on reform, impatience of powerful groups with inappropriate rules of property, indifference of counsel and court-the Rule in orthodox form has been updated since Gray wrote. Applying Gray's Rule presupposes classification of future interests in the dispositive instrument as a prerequisite to determining validity under the Rule. The rub is that meticulous characterization of future interests is seldom found in modern perpetuities cases. Limitations are not standardized and readily recognizable as falling within a particular category in the future interests hierarchy. Ambiguities frequently abound, and it is sometimes almost impossible to assimilate the half-articulated expressions of the grantor or testator to the ideal types which illustrate the black letter rule. Limited space precludes extended illustrations, but consider the dispositive language in Second Bank-State St. Trust Go. v. Second Bank-State St. Trust Co. ${ }^{156}$ In 1930 Allan Forbes created an irrevocable trust to pay the income to himself for life and then to his wife, Josephine, for life. Thereafter income and principal were distributable as follows:

the said trust estate shall be held in trust for the benefit of the children of the said Allan, and the issue of any child who may have deceased, each child to receive an equal share of the net income therefrom during his or her life. The share of any child who shall die leaving no issue surviving him or her shall be held in trust for the equal benefit of the surviving children of the said Allan, and the issue of any deceased child, taking by the stocks; and the net income therefrom shall be paid over equally to such surviving children during their lives, and to the issue of any deceased child, such issue taking their parents' share. If any child of the said Allan shall die leaving issue, his or her share shall be held in trust for the benefit of such issue, and the net income therefrom paid over to such issue, per stirpes, or to their legal guardian..., until the termination of this trust. At the expiration of twenty-one years after the death of the last survivor of the children of the said Allan, this trust shall terminate, and the trust estate shall then be distributed among such issue, per stirpes, and not per capita; and until the termination of

156335 Mass. 407, 140 N.E.2d 201 (1957). 
this trust, the trust estate shall be held together, and administered as one trust. ${ }^{157}$

After Allan Forbes died, his executors sought a declaration respecting the validity under the Rule of the remainder interests in principal, arguing that the ultimate number of persons sharing in principal might not be fixed within the perpetuities period, as required by the rule of Leake $v$. Robinson, ${ }^{158}$ that the gifts of principal were therefore void, and that there was a resulting trust to Allan Forbes' estate.

Under the rule of Cattlin v. Brown ${ }^{159}$ the gift of principal to issue of a child of Allan Forbes alive at the creation of the trust would be good under the Rule Against Perpetuities if the size of the share of principal represented by such child of Allan Forbes would necessarily be fixed within the perpetuities period. The identification of issue of such child sharing in such gift of principal would pose no perpetuities problem because identification would necessarily be made within the lifetime of their ancestor, a person in being at the creation of the trust in 1930. In Second Bank the minimum size of the share of principal represented by a child of Allan Forbes alive in 1930 would be fixed at Allan Forbes' death; but the maximum size of such share might not be fixed until a remote time, for the survivor of the children of Allan Forbes might be a child unborn in 1930, and such afterborn child of Allan Forbes might die leaving no issue. If so, the share of principal represented by such afterborn child of Allan Forbes would pass to issue of children of Allan Forbes who survived their ancestors, and such issue might include issue of a child of Allan Forbes alive in 1930. If the dispositive language permitting the fatal increase in size could be severed from other dispositive language, the gift of principal to issue of a child of Allan Forbes alive in 1930 could be saved. ${ }^{160}$ Nowhere in the opinion of the court in Second Bank is the necessity for severance explained or the ease of severance demonstrated. Nowhere in the opinion is there the careful characterization of future interests which is a prerequisite to applying the Rule. Nevertheless, the gifts of principal withstood attack because the highest court of Massachusetts found them protected by the rule of Cattlin, and the

\footnotetext{
${ }^{167} I d$. at 408,140 N.E.2d at 204.

${ }^{268} 2$ Mer. 363, 35 Eng. Rep. 979 (Ch. 1817).

${ }^{100} 11$ Hare 372, 68 Eng. Rep. 1319 (Ch. 1853).

2006 A.L.P. $\$ 24.29$ n.1.
} 
settlor, Allan Forbes, had no children after he created the trust in 1930.

What do courts do in cases like Second Bank when working within the area of freedom accorded to them by the words of the instrument, the rules of construction, and the intricacies of the Rule Against Perpetuities itself? Limitations which on orthodox grounds might be classified as contingent and subject to the Rule are classified as vested and exempt from the Rule. Contingent remainders, contingent executory interests, possibilities of reverter, and rights of entry for condition broken are being assimilated. The elusive line between contingent and vested remainders is disappearing altogether. ${ }^{161}$ A single piece of paper now does tasks once thought achievable only through two. Courts grope toward a possessory test of validity under the Rule which has been suggested by Simes ${ }^{102}$ (with reservations) and endorsed by Schuyler. ${ }^{103}$

Although Gray's classic formulation of the Rule is often invoked only as a formality in recent perpetuities cases, it does not follow that the common law Rule Against Perpetuities has lost all function. On the contrary, in its fumbling fashion the Rule does keep madmen with property in check, both directly, by invalidating dispositions that transgress permissible limits, and indirectly, by alerting draftsmen to the dangers of intemperate, indiscriminate creation of future interests. lrrespective of the form which the Rule takes, there are likely to be cases which apply it badly; and in the close cases, the actual grounds for decision will probably remain conjectural. The common law Rule Against Perpetuities is neither perfect in conception nor clear in application, but due primarily to Leach, it has been modernized. Simes's fears notwithstanding, ${ }^{104}$ it will be with us for a long, long time.

\footnotetext{
101 DUREMINIER 14.

${ }^{162}$ Simes, Public Policy and the Dead Hand 80 (1955).

${ }^{103}$ Schuyler, Should the Rule Against Perpetuities Discard Its Vest? (pts. I-11), 56 Mich. L. REv. 683, 887 (1958).

${ }^{104}$ Simes, supra note 131.
} 